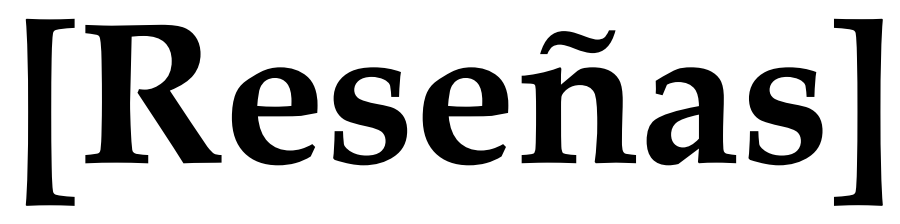





\section{Manuel González de Ávila, Cultura y razón. Antropología de la literatura y de la imagen, Rubí (Barcelona), Anthropos, 2010, 301 pp.}

Son necesarios libros como el de Manuel González de Ávila en un marco contextual como el actual, en el que el sempiterno cuestionamiento del conocimiento humanista parece haber llegado a su punto más álgido por los avances tecnológicos, el progresivo arrinconamiento de sus disciplinas en los nuevos planes de estudios, el desarrollo de la crisis económica -que ha llevado a diversos sectores sociales a reclamar una formación básicamente utilitarista que permita una rápida rentabilidado el ascenso que, escondidas bajo el disfraz de la globalización, han llevado a cabo las más salvajes formas de capitalismo. Más allá de su valor científico -que lo tiene, y mucho-, la necesidad de Cultura y razón. Antropología de la literatura y de la imagen nace de su condición de llamada de atención sobre el futuro de las Humanidades y las Ciencias Sociales y, sobre todo, de su capacidad para proponer una alternativa viable tanto para superar el descrédito y la desafección que parecen rodear ambas disciplinas como para hacer que la producción de conocimiento sobre el mundo social y cultural no se vea obligada a justificar de forma recurrente su existencia. De hecho, ya en los primeros párrafos de la obra González de Ávila -cuya teoría parte de un exhaustivo dominio de las principales corrientes filosóficas, antropológicas, literarias y artísticas de la actualidad, a las que acude puntualmente para sostener sus argumentos con unas soltura y concisión que sólo permite el conocimiento en profundidad- deja claro cómo su principal propósito es el de vincular los saberes humanísticos a los de las ciencias sociales, proponiendo el empleo del neologismo "ciencias sociohumanas" como marco capaz de englobar la diversidad que suponen los estudios de la Teoría de la Literatura, la Literatura Comparada, la Cultura Visual, la Antropología, la Sociología, la Historia o el Arte. Parafraseando al autor, podría decirse que lo que pretende su propuesta es generar una fuente de conocimiento global y complementario que permita, a partir de la aplicación de bases antropológicas al estudio artístico, de la vinculación del método humanista al estudio social y del diálogo entre las ciencias naturales y las que se proponen como "sociohumanas", la creación de una "teoría práctica y de una práctica teórica decidida a proteger la historia común de la humanidad y a salvaguardar los procesos de cambio social". En ese sentido, resulta sumamente acertado que el libro haya sido publicado en el catálogo de una colección editorial llamada "Pensamiento crítico / Pensamiento utópico".

Dividido en tres grandes capítulos ("Epistemología”, “Literatura” e “Imagen”), el libro se estructura en torno a breves epígrafes -de no más de cinco o seis páginasque evidencian la capacidad del autor para vincular temas y para establecer, como elemento adicional a la teoría unificadora sobre las Ciencias Sociales y las Humanidades que domina la línea argumental de la obra, diversas reflexiones sobre los estudios contemporáneos sobre literatura e imagen. De este modo, González de 
Ávila parece poner en práctica los propios postulado teóricos que defiende, pues la misma necesidad de no limitar ni hacer del conocimiento una parcela especializada y particular imposibilitada de generar diálogo con otros campos que reclama su propuesta de "ciencias sociohumanas" reside en sus análisis sobre la cultura y el arte actuales, integradores e interdisciplinares.

A pesar del innegable interés de todo el libro, y de la unidad que, dentro de la variedad de asuntos en él tratados, posee, es el capítulo dedicado a los estudios literarios el que, por su contenido y enfoque, resultará más sugestivo para los investigadores vinculados a la literatura en general, y a las disciplinas teóricas y comparatistas en particular. En ese capítulo, González de Ávila analiza, en primer lugar, la viabilidad de la disciplina de la Teoría de la Literatura, a la que, refutando las opiniones de aquello que sostienen que los andamiajes teóricos han sido los principales causantes de la crisis de las humanidades al hacer rutinario y mecánico un objeto de estudio que tendría que ser tan voluble como su propio origen humano indica, proclama necesaria siempre y cuando sea capaz de ajustarse al proyecto antropológico que reclama todo el libro. Así, el autor demanda "una teoría verdadera y suficientemente científica de la literatura, que la saque de los saberes humanísticos para emplazarla entre las ciencias sociohumanas".

También se ocupa el capítulo del futuro del comparatismo literario, al que sitúa como una disciplina necesariamente holocultural -y, evidentemente, "sociohumana"destinada a superar la tradicional dialéctica entre comparación retórica y comparación científica para convertirse en un marco científico, histórico, social y artístico que, tal y como indicó Itamar Even-Zohar, pueda insertar al texto dentro del polisistema -y de las complejas relaciones que lo forman- en que se inscribe. Con semejante método, que no esconde las evidentes vinculaciones entre la literatura comparada y la antropología cultural, la comparación podría convertirse en una vía de conocimiento racional que ahondase en el conocimiento y la comprensión de los textos.

El capítulo titulado "Literatura" se completa con unas interesantísimos reflexiones acerca de la historiografía, la autobiografía o la identidad que resultan de suma clarividencia en un momento como el actual, en el que las denominadas "literaturas de la memoria" y "literaturas del yo" están conociendo un inusitado apogeo gracias al auge del género autobiográfico, a la proliferación de textos autoficcionales, al trasvase del discurso autobiográfico al cómic o el cine, al exhibicionista culto al yo que parece dominar la sociedad, a la proliferación de corrientes como la microhistoria o al "culto a la memoria" que, en palabras de Jacques Derrida, parece vivirse en el mundo contemporáneo, cuya obsesión por recordar puede detectarse, además en la citada eclosión autobiográfica, en la proliferación de archivos y centros documentales, en la continua conmemoración pública de onomásticas o en procesos sociales como la denominada "recuperación de la memoria histórica" desarrollada en diversos países durante las últimas décadas. Además de encajar con el proyecto metodológico expuesto en la obra, las reflexiones sobre estos temas permiten dar un lugar en los estudios "sociohumanísticos" a un discurso como el autobiográfico, permanentemente cuestionado en los postulados clásicos de la teoría literaria por su vinculación con 
la representación referencial del mundo, y demuestran la vigencia del libro, también evidenciada en el capítulo dedicado a los estudios de imagen, en los que González de Ávila, lejos de limitar sus reflexiones a la pintura, el cine o la fotografía, se ocupa también de manifestaciones como el videoarte.

Cultura y razón. Antropología de la literatura y de la imagen es, en definitiva, una inteligente respuesta a la situación de los estudios humanísticos. Meditado, coherente, bien documentado y tremendamente actual -sin dejar por ello de contener conclusiones de dimensiones universales susceptibles de trascender la contemporaneidad de su gestación-, el libro puede ser leído como una propuesta sobre lo que han de ser en el futuro los estudios literarios y artísticos $-\mathrm{y}$, en otro orden de cosas, sobre la formación global, interdisciplinar y "sociohumana"que, similar a la que demuestra poseer González de Ávila, han de tener quienes se enfrenten a ellos- y, al mismo tiempo, como un compendio de lúcidas reflexiones sobre diversos aspectos del arte, la cultura y la sociedad contemporáneas. Desde cualquiera de las ópticas, la obra resulta tan interesante como necesaria y, por tanto, recomendable.

Javier Sánchez Zapatero 



\section{AAVV. Homenaje a Miguel Hernández en su centenario. 1910-2010. Prólogo y edición de Maricel Mayor Marsán. Miami: Ediciones Baquiana, Colección “Caminos de la poesía", 2010, 125 pp.}

Al finalizar la primera de las décadas del siglo XXI, se ha evidenciado que la bibliografía suscitada por Miguel Hernández no sólo es una de las más copiosas que haya generado un escritor hispano moderno y contemporáneo, sino que sigue creciendo de continuo, y desde las distintas vertientes que un poeta ofrece: investigaciones biográficas sobre su vida, así como libros y artículos acerca de su obra. Pero el escritor de Orihuela, además, ha inspirado e inspira a numerosos artistas plásticos, al igual que a creadores de cada uno de los tres grandes ámbitos de la literatura: la novela, el teatro y la poesía.

Ahora bien: siendo él preferentemente un poeta, a nadie puede extrañar que hayan sido sobre todo los poetas quienes figuren al lado de los investigadores a la hora de nutrir ese caudal bibliográfico que, parecidamente al rayo, tampoco cesa. A la altura de 2010, cuando se han cumplido los cien años de su nacimiento, y con motivo de la publicación del volumen Homenaje a Miguel Hernández en su centenario, libro ideado, coordinado, editado y prologado por la escritora Maricel Mayor Marsán, podemos recordar que Miguel Hernández ya inspiró poemas hace más de ochenta años, cuando apenas habían aparecido unos pocos versos suyos en la prensa local. Y es que, en efecto, su amigo de juventud Carlos Fenoll ya compuso en su honor el poema "La sonata pastoril", fechado en Orihuela mismo, el 30 de septiembre de 1929.

En sus versos, Carlos Fenoll se refería a "este pastor ique ha nacido para cantar a su huerta!". Pero no podía imaginarse ese vecino de Miguel Hernández, que tuvo por oficio el de panadero, que ese compañero de aficiones, de fatigas, de contadas alegrías y de numerosas penas, no iba a circunscribir su canto a la huerta oriolana, sino que con el tiempo crearía dos de las obras poéticas más cimeras de la poesía española contemporánea: El rayo que no cesa y Cancionero y romancero de ausencias. Y mucho menos podía sospechar aun que Miguel Hernández sería estudiado, cantado y homenajeado en todos los continentes, pero sobre todo en España y en suelo americano.

Si Carlos Fenoll fue quien se anticipa en cantarle en España, Rafael Alberti sería quien primero le canta en tierras de América cuando, en 1942, y a raíz de la muerte del oriolano en prisión, compuso en su memoria su "Égloga fúnebre a tres voces y un toro para la muerte lenta de un poeta". Desde entonces y hasta el comienzo del tercer milenio, Miguel Hernández ha sido motivo de frecuente e intensa lectura e inspiración en los diversos países americanos, y tanto por parte de los estudiosos de su obra como por la de creadores de las diversas ramas artísticas, y en esa línea de homenajes surgidos en América se inscribe este originalísimo libro conmemorativo que da pie a mi comentario, un libro en el que, bajo la segura y entusiasta guía de 
Maricel Mayor Marsán, y editado en Miami por Ediciones Baquiana, han participado cincuenta creadores residentes en distintas latitudes del variado mapa territorial de los Estados Unidos, y para el que han realizado diversas creaciones plásticas y literarias.

Ilustra la portada de este Homenaje a Miguel Hernández en su centenario una fotografía en color, y en la que contrastan luz y sombra, instantánea muy representativa de la vida y del ambiente doméstico del poeta oriolano. En ella se capta un espacio emblemático del huerto en el que tantas horas pasó y en el que su imaginación perfilaría tantos ensueños literarios y crearía tantos versos. En ese espacio vemos el redil en el que guardaba las cabras que tantas veces pastoreó, pudiéndose ver también un trozo de la montaña que se alza detrás de la casa familiar, hoy convertida en casamuseo de Miguel Hernández. Un formato más reducido tiene la fotografía que ilustra la contraportada del libro, y en la que contrastando de nuevo sombra y claridad, se capta la ventana de la habitación que ocupó el poeta en su casa oriolana.

La obra va precedida de un prólogo de la compiladora para el que ha escogido un título muy sugerente, el de "Miguel Hernández, ruiseñor de desdichas". Y no cabe duda de que esa expresión de "ruiseñor de desdichas", que él se aplicaba a sí mismo, resulta muy adecuada para caracterizar, en síntesis, sus tribulaciones históricas, en las que experimentó penalidades e infortunios sucesivos hasta la desdicha final de su muerte en prisión. Pero tampoco cabe la menor duda de que Miguel Hernández se habría sentido muy gratificado si hubiese podido alcanzar a ver el amplio reconocimiento que generación tras generación concita su figura y la enorme repercusión filológica y artística que propicia su obra literaria, y de la que este libro es una dignísima muestra.

En su prólogo explica Maricel Mayor Marsán cómo, en sus diferentes viajes a España, se acercó varias veces a la región de Levante en la que nació, vivió, escribió y murió Miguel Hernández, y por supuesto visitó la ciudad de Orihuela, y ahí conoció la casa familiar del poeta. Y no cabe duda de que ese conocimiento directo de los ámbitos concretos en los que se inscribe el perfil y el carácter esencial de la obra del autor de El rayo que no cesa no sólo hicieron crecer en ella su interés y admiración hacia el oriolano, sino que han nutrido sus esfuerzos por difundir su figura, su obra y sus mensajes con ocasión de este primer centenario de su nacimiento. $Y$ aquí hay que añadir, y remarcar, que en su compromiso conmemorativo no le ha faltado el estímulo y el aliento de la Fundación Cultural Miguel Hernández a través de sus dos principales impulsores y gestores, Juan José Sánchez Balaguer y Aitor L. Larrabide.

Considero que este libro tiene un precedente en una anterior aportación al hernandismo realizada por Maricel Mayor Marsán. Me estoy refiriendo al estudio de la autora que fue publicado en el volumen colectivo Presente y futuro de Miguel Hernández, título que se puso a las Actas del II Congreso Internacional sobre el poeta celebrado en el año 2003, y que coordinó Aitor L. Larrabide, siendo sus editores Juan José Sánchez Balaguer y Francisco Esteve. En su día, a aquel trabajo le dio Maricel Mayor Marsán la titulación de “Miguel Hernández: más allá de la poesía y el folklor (Presencia e impacto de su obra en los EE.UU)", una titulación indicativa de que este 
trabajo se ocupaba de la repercusión de la obra del poeta en USA, ya por entonces muy notable, pero circunscribiéndola al campo específico de la investigación filológica.

Pese a estar limitado a dicha área, y pese a tratarse de un artículo, y no de un libro, esa contribución de la autora al hernandismo entronca con ese Homenaje a Miguel Hernández en su centenario, pero a la vez que entronca lo hace desde una perspectiva distinta. Se vinculan esas dos aportaciones porque se centran en ilustrar la estela del poeta oriolano en los Estados Unidos, pero el estudio aparecido en 2003 se ceñía al ámbito de la investigación académica, y el de 2010 abarca diversas opciones creativas, pudiendo afirmarse que ambas contribuciones bibliográficas se asocian entre sí, pero al propio tiempo resultan complementarias la una de la otra, a la vez que a ambas las une y las identifica el entusiasmo y el buen hacer y la eficacia de Maricel Mayor Marsán, quien en Miami ha querido y ha sabido unir dos claves representativas de ese espacio de Florida en el que vive y en el que desarrolla principalmente sus actividades intelectuales: el fervor debido a sus raíces hispánicas, y la preocupación por el logro de la eficacia en los objetivos emprendidos, y que está en consonancia con el carácter estadounidense que desde hace tantos años tiene la ocasión de apreciar y de asumir en el día a día.

Decíamos antes que en Homenaje a Miguel Hernández en su centenario participan cincuenta creadores, entre los cuales se cuenta la realizadora del libro, Maricel Mayor Marsan. Cifra redonda, ciertamente, la de ese conjunto de medio centenar de autores reunidos para la conmemoración de una cifra doblemente redonda, la de la centena primera del nacimiento, en Orihuela, del autor homenajeado. Decíamos antes también que todos los que han participado en este tributo residen en diferentes territorios estadounidenses, pero ahora toca precisar que, de ellos, el más representado es Florida, porque los creadores residentes en este Estado suponen la mitad de los participantes en la obra, y siguiéndoles, a notable distancia, los que viven en Nueva York, y a más distancia todavía los que tienen su casa en Texas y Nuevo México. Y no son sólo esos cuatro los Estados que tienen representación en el libro, porque son media docena más, aunque su presencia en él resulta testimonial, si bien no menos interesante y significativa.

Por lo que hace al lugar de origen de quienes han ofrecido su homenaje creativo al poeta levantino, casi la mitad de ellos son cubanos, seguidos muy de lejos por autores nacidos en México, Colombia y Puerto Rico. Podría hacer mención asimismo de la procedencia de los demás componentes de esa nómina de creadores, pero para no extenderme diré que en el elenco de participantes figuran varios nacidos en USA, uno en Brasil, dos en España y uno en Italia. A modo de resumen de cuanto se acaba de señalar, se desprende que el peso más sustancial de este libro pensado y editado en Miami le ha correspondido, sin desdoro de cualesquiera otras participaciones, a la de Florida, y en ella a la nutridísima contribución cubana, una vez más ligada a la memoria de Miguel Hernández.

El poeta oriolano fue un escritor cuyo quehacer se manifestó en varias vertientes, pues no sólo compuso poemas, sino que elaboró piezas teatrales, desarrolló una gran 
actividad periodística y hasta creó textos narrativos en prosa. Pero no cabe duda de que el campo en el que iba a distinguirse fue el de la poesía, y seguramente es por ese motivo que es a los poetas a quienes más ha interesado, interesa e interesará su obra. Es ésa una realidad bien lógica, y el libro Homenaje a Miguel Hernández en su centenario la refleja. Y es que, en efecto, más de dos tercios de la obra son composiciones poéticas, complementándose la misma con muestras de narrativa, de fotografía y de artes plásticas, como el dibujo, y hasta en un caso la escultura, trasladada a las páginas mediante la fotografía.

Son numerosas las creaciones coleccionadas en este libro por Maricel Mayor Marsán que en su título citan expresamente el nombre de Miguel Hernández, o hacen referencia a poemas o a versos suyos, cuando no a su mundo y a sus circunstancias. Sin embargo, con independencia de tales o cuales referencias expresas, lo que se percibe en la obra es que el influjo del poeta de Orihuela, y asimismo el homenaje a su vida y a su literatura, está en todas y en cada una de las contribuciones a este tributo al autor del Cancionero y romancero de ausencias.

Diré también que, aun cuando todas las participaciones de estelibro seencaminan a un mismo fin, el del homenaje, la variedad de tonos y de perspectivas conducentes a él son muy diversas, y no sólo porque Maricel Mayor Marsán ha querido que en esta obra convivan diferentes generaciones, sino porque las estéticas son en muchos casos bien diferentes unas de otras, y lo son desde la clase de corriente desde la que se crean, desde el punto de vista adoptado, desde la modalidad textual elegida, sea elegíaca, sea recreadora, sea memorialística, etc.

Me parece de justicia remarcar, asimismo, la alta calidad de las contribuciones a esta obra, lo que era esperable si atendemos al excelente, rico y vario currículo de quienes han participado en ella. Es cierto que ese currículo es más breve en los casos de personas pertenecientes a las generaciones más jóvenes, pero ya se adivina en ellas que están apuntando a una gran proyección, y que ya hoy merecen figurar al lado de tantas trayectorias desarrolladas, muchas desde la filosofía y la cátedra, y cuya solvencia se ha visto reconocida con puestos profesionales de relieve y con la obtención de premios de carácter internacional.

Al término del poema inicial de El rayo que no cesa, hizo Miguel Hernández un pronóstico nada difícil de aventurar: “...Algún día/ se pondrá el tiempo amarillo/ sobre mi fotografía". Sin embargo, ante la realidad fehaciente de este libro publicado en Miami, no considero demasiado atrevido por mi parte pronosticar que la obra hernandiana, y especialmente su poesía, que ya ha ganado el presente, también tiene trazas de que va a ganar el futuro.

José María Balcells 
Javier Sánchez Zapatero y Àlex Martín Escribà (eds.), Realidad y ficción criminal. Dimensiones narrativas del género negro, Valladolid, Difácil, 2010, 267 pp.

Este libro, nacido en el contexto del V Congreso de Novela y Cine Negro, celebrado en la ciudad de Salamanca, supone una aportación actual y heterogénea al panorama literario especializado en género negro. Javier Sánchez Zapatero y Àlex Martín Escribà en su labor de editores -y directores de congreso desde 2005-, se han encargado de compilar una serie de artículos de carácter científico que se construyen en torno a las dimensiones narrativas del género. De estas cuestiones teóricas surgen textos firmados por críticos cinematográficos como Juan Antonio Pérez Millán, profesor y actual director de la Filmoteca de Castilla y León, estudiosos de la literatura como los propios editores $\mathrm{u}$ otros investigadores de centros nacionales e internacionales, creadores literarios como Domingo Villar o Suso de Toro, o amantes del género negro que han querido reflexionar sobre la ficción literaria como el filósofo Fernando Savater.

En su afán aglutinador, Realidad y ficción criminal. Dimensiones narrativas del género negro, se compone de artículos que conforman los últimos estudios en torno a la relación del género negro con la ficción novelada o filmada. Así, Javier Rodriguez Pequeño Universidad Autónoma de Madrid- escribe sobre el concepto de verosimilitud puesto en relación con la novela negra, y Nacho Faerna -escritor y guionista- titula su artículo, en el que reflexiona sobre los límites entre la novela y el testimonio en los parámetro de la literatura negra, Ficción y realidad criminal. En el libro también tienen cabida las aportaciones vertidas al panorama teórico desde el ámbito de la creación literaria. De este modo, el escritor Domingo Villar recoge en su texto los principios fundamentales de su obra -protagonizada por el policía Leo Caldas- y, por su parte, el escritor gallego Suso de Toro reflexiona en torno a la naturaleza del género policiaco y su desarrollo en contextos rurales. No obstante, este libro también supone una apertura hacia otros ámbitos que relacionan, en este caso, la literatura negra y policiaca con el contexto en el que surgen. Agustín Reyes-Torres -Universidad de Virginia- estudia la figura del detective afroamericano y la confronta con su realidad racial y el propio Javier Sánchez Zapatero propone un estudio circunscrito a la literatura negra sueca, centrado en la figura del escritor Henning Mankell. Las literaturas catalana y mexicana son otros de los ámbitos en los que se centran algunos de los estudios analíticos incluidos en el texto.

El libro tampoco descuida realidades cada vez más pujantes en el panorama negro-policiaco. Así, María Marcos Ramos -Universidad de Salamanca- propone un estudio de la violencia en los medios audiovisuales y los efectos que esta puede tener en el espectador, mientras que el periodista Manuel López Poy ahonda en las relaciones entre el género y la música blues. 
Realidad y ficción criminal. Dimensiones narrativas del género negro no solo es un texto de carácter científico, ya que reserva sus últimas páginas a la creación literaria perteneciente al género negro. De este modo, son tres los escritores que han colaborado, aportando sus creaciones literarias para la ocasión: Antonio Marcos Sánchez, Eugenio Fuentes y Luis Gutiérrez. Esta apuesta por la creación literaria de actualidad, supone un complemento al apartado teórico-reflexivo y, al mismo tiempo, es una buena oportunidad para conocer a escritores de género que están empezando o, como en el caso de Fuentes o Gutiérrez, disfrutar de autores ya consagrados en la ficción negra.

El libro es una valiosa contribución a la bibliografía de género especializada en lengua española -no demasiado amplia hasta la fecha- y se erige, al igual que el Congreso en el que tiene su origen, como una referencia obligada en el panorama literario actual y, más concretamente, en el ámbito del estudio de la genología literaria y las narrativas populares.

Javier Voces Fernández 


\section{Miguel Ángel García, Un aire oneroso. Ideologías literarias de la modernidad en Es- paña (siglos XIX-XX), Madrid, Biblioteca Nueva, 2010, 354 pp.}

Los tiempos que vivimos son confusos, como diría el maestro Pasolini en uno de los pasajes de «Una polémica en versos» de su célebre oda civil Las cenizas de Gramsci: «L'ora è confusa, e noi come perduti / la viviamo [...]». No en vano en Un aire oneroso. Ideologías literarias de la modernidad en España (siglo XIX-XX) se comienza recordando y citando otros célebres versos pasolinianos del homónimo poemetto: «Non è di maggio questa impura aria», haciendo alusión a ese aire pesado, gravoso, que flota a nuestro alrededor. La metáfora no puede ser más clara, y los versos nos ponen frente al problema: el aire que respiramos está corrompido o, atendiendo a la primera cita, vivimos como perdidos en un tiempo confuso, sin tener conciencia de lo que sucede mientras que el mundo sigue dando vueltas velozmente, acumulando cada vez más injusticias.

Esta suerte de confusión podría entenderse también como una narcosis que, continuando con la línea de este libro que reseñamos de Miguel Ángel García, profesor titular de Literatura Española de la Universidad de Granada, podría definirse mejor que nunca como «narcosis ideológica». El consumo en el que estamos envueltos sería sólo la capa más superficial y visible de esa trabazón que nos tiene ciegos, maniatados y mudos, que nos hace repetir como autómatas lo que el pensamiento dominante ha diseñado que digamos, veamos, repitamos y, en suma, seamos. Nos controlan hasta los deseos que pensamos más oscuros e individualizados (junto a nuestra pretendida individualidad), pues responden a concretas situaciones sentimentales históricas, y en eso consisten las corrientes ideológicas dominantes: no podemos salir de ellas.

Quizá lo único que se pueda hacer ante este aire que nos ha tocado respirar es tomar conciencia de su realidad corrosiva. Pero desde el pensamiento combativo de las últimas décadas lo que brilla por su ausencia precisamente es la toma de conciencia, ya que se ha generalizado un menefreguismo (término que se ha extendido en castellano también del italiano, de me ne frega, «no me importa») total, un caos desbordante. Ciertamente la falta de compromiso político es un síntoma de nuestros tiempos, que viven como natural el capitalismo avanzado, y cualquier otra alternativa de sistema económico, político, etc., se concibe como una alteración de ese orden natural -o dicho mejor, naturalizado - que se ha impuesto a cualquier otra concepción ideológica. La caída de la Unión Soviética no sólo supuso la derrota de una dictadura de facto que arruinó la revolución universal con las teorías estalinianas de la revolución dentro de la nación, frente a las internacionalistas de Trotsky. Supuso mucho más, porque la utopía se vio desmantelada en pocos años y cualquier tentativa de lucha por un mundo más justo y alternativo al capitalismo salvaje se considera como un despropósito, una suerte de intervención en el ciclo natural económico y social del hombre (porque parece ser y quieren convencernos de que lo natural del hombre es ser injusto). Dicen 
que el capitalismo es el sistema menos injusto de los que existen, extendiendo así la conocida frase aplicada a la democracia. Sin embargo muchos millones de personas todavía piensan en el planeta que no es cierto, y que lo que se está justificando es la miseria de la mayoría por el lujo y el fasto de unos pocos. Lo absolutamente nefasto de todo esto es que cualquier intento alternativo no tiene lenguaje para transmitir la transformación del mundo que pretende.

Dividido en diez capítulos y una introducción, Un aire oneroso. Ideologías literarias de la modernidad en España (siglo XIX-XX) es un recorrido sistemático y riguroso por la literatura desde Gustavo Adolfo Bécquer a Juan Ramón Jiménez, realizando en cada uno de ellos una escala profunda y sesuda sobre el estado de la cuestión de los autores o corrientes que desarrolla, tales como Rubén Darío, Campoamor, Ángel Ganivet, Valle-Inclán, el 98, el modernismo, la bohemia, Antonio Machado y Azorín, etc. La bibliografía es muy interesante, siempre atinada, y el lenguaje muy compacto, o mejor dicho, compactado, con escasez de comas y signos de puntuación (lo cual a veces hace las frases demasiado largas y hay que leerlas dos veces), evitando con eso pausas innecesarias. Esta propuesta de puntuación no es una casualidad, sino que forma parte de un determinado estado de escritura y pensamiento que merecería la pena calibrar más a fondo, pero que nosotros, ahora, en cualquier caso agradecemos enormemente. El profesor Miguel Ángel García da un repaso riguroso por los diferentes temas y capítulos recogidos, efectuando una puesta al día de algunos de los conceptos más peliagudos y a veces poco atractivos, de la literatura española, sin ambages ni anfibologías, criticando cuando tiene que criticar y señalando lo que le gusta cuando lo cree oportuno. En ese sentido estamos frente a un libro atrevido y que no se anda por las ramas. El marxismo como herramienta, como sistema total de pensamiento, no es aquí un mero utillaje teórico que nos acompaña en nuestros razonamientos, donde insertamos una noción más o menos osada o provocativa, sino una teoría general de las sociedades en movimiento aplicada a la literatura. Sin embargo durante el siglo XX, y sobre todo a finales, precisamente encuadrándose en la disolución del lenguaje de la izquierda y la caída de las utopías, los diferentes enfoques de la literatura estuvieron tan discutidos como la pretendida cientificidad de la Historia, abanderada por aquellos marxistas que luego acabaron cometiendo tantos errores para el pensamiento filosófico y político de izquierdas. A partir de estas premisas se plantean las problemáticas más interesantes e importantes por las que ha atravesado el «continente historia», hasta llegar a la desustancialización que supuso la posmodernidad con las consignas liberales de Fukuyama, aplicadas por Lyotard a la literatura: una historia que ha tenido que renunciar, como se sabe, a los grandes relatos, ya que vivimos una realidad fragmentada.

Pocos podemos añadir a un libro tan bien argumentado y presentado que no sean meros aspectos formales, ya que en lo tocante al fondo la escrupulosidad de Miguel Ángel García es realmente impresionante. Ya nos tenía acostumbrados con entregas como Vicente Aleixandre, la poesía y la historia (Comares, 2001), que fue su tesis doctoral; El Veintisiete en vanguardia (Pre-Textos, 2001), con el que consiguió el Primer Premio Internacional de Investigación Literaria Gerardo Diego; La poética de lo invisible en Juan 
Ramón Jiménez (Maillot Amarillo, 2002); o el muy reciente «Sin que la muerte al ojo estorbo sea». Nueva lectura crítica de Francisco de Aldana (Editora Regional de Extremadura, 2011). Sus obras son ciertamente para iniciados, no para esa inmensa minoría juanramoniana - que eran muchos más de lo que en primera instancia se supone, como bien demuestra el profesor García - sino para un exclusivísimo haz de estudiosos e iniciados que manejen ese lenguaje que además tendría como objetivo romper con esa jerga de la autenticidad (recordando a Adorno) que postula «una auténtica historia marxista de la literatura». Eso es imposible, claro está. Pero cualquier filólogo que haya seguido los pasos de Miguel Ángel García sabrá que nos encontramos ante uno de los estudiosos marxistas de la literatura más destacados del panorama actual, con unos planteamientos bien asentados y afirmados que ofrecen pocas dudas, sí disensiones o debate, pero desde una seriedad terminológica y metodológica muy bien articulada. No hay una sola lectura literaria de una obra, como tampoco hay una sola historia, sino diferentes relatos - narrativos, semióticos - que se van construyendo poco a poco en función de diversos intereses. Habrá que atender principalmente a ver quién los construye y por qué, de qué modo, cuáles son sus pros y sus contras, pero lamentablemente, igual que ya no aspiramos a construir un gran relato, como ya hemos dicho, hay que saber también cuáles son los fragmentos importantes que tenemos que recoger, que están ahí esperando ser recogidos, pues se trata de saber reconstruir una historia válida para cada momento, para cada circunstancia. No podemos seguir pensando como se pensaba hace medio siglo, y Miguel Ángel García actualiza el pensamiento marxista y lo aplica a la literatura. Sólo así podemos entender y emprender la transformación del mundo y del hombre.

Juan Carlos Abril 



\section{Rosa Sanmartín Pérez, La labor dramática de Manuel y Antonio Machado, Granada, Ediciones Mágina, Editorial Octaedro Andalucía, 2010, 220 pp.}

Se trata de un libro particularmente estimado y hasta diría que nostálgico para mí, puesto que enfoca un asunto del que me vengo ocupando desde 1970; es decir, hace más de cuarenta años. Fue entonces cuando comencé mi memoria de licenciatura, bajo la dirección del doctor Orozco Díaz, catedrático de la Universidad de Granada, que hizo que me interesara por el teatro machadiano cuando todavía nadie se ocupaba de ese asunto, pues no existía sobre él más que en el espléndido artículo de Eusebio García Luengo en Cuadernos hispanoamericanos XI-XII, de 1949, y posteriormente el libro de Manuel H. Guerra de 1966, que llegó a mis manos cuando tenía muy avanzado el estudio. Aquel primer trabajo, que constituía mi memoria de licenciatura (La obra dramática de Manuel y Antonio Machado, Universidad de Granada, 1971) poseía tan inusual extensión (dos volúmenes, 1005 páginas), que tuve que justificarlo por consejo de Orozco en el prólogo, porque incluso para lo que entonces "se estilaba" parecía excesiva extensión. Así constaba: “Queremos desde un principio curarnos en salud respecto a la extensión de esta obra, anormal para una memoria de licenciatura; pero creemos firmemente que si este estudio es un acopio de material en su mayor parte inédito, no podía ser de otra manera. Además, los años de las síntesis no son precisamente los juveniles y debemos estar de acuerdo con nuestra edad (22 años): ahora se impone el analizar, pensar e investigar para llegar con el tiempo a conclusiones válidas que puedan incluirse en sólo dos líneas de un libro".

De ese trabajo de 1971 fueron surgiendo sucesivas publicaciones, comenzando por la misma tesis doctoral (En el contexto de teatro en verso: los Machado y Ángel Lázaro. Un intento de aproximación a través de la crítica), defendida en la misma universidad granadina en 1975 y cuyo resumen aparecía como publicación en 1976, además de otros estudios que culminaron en la edición de todas las obras teatrales machadianas, la última de las cuales (El hombre que murió en la guerra) ha aparecido en EspasaCalpe, $\mathrm{n}^{\circ} 624$ de la Colección Austral, Madrid, 2008. Por eso el ver ahora un libro de asunto e incluso de título tan similar, escrito por persona joven y con idéntico ímpetu, transcurridos cuarenta años, me llena de nostalgia y me permite, siquiera por breve tiempo, adentrarme de nuevo en un asunto que me fue y es particularmente querido. Únese a ello el formado parte del tribunal que juzgó y calificó la tesis doctoral de la profesora Rosa Sanmartín, que defendió con absoluto éxito en la Universidad de Valencia hace un par de años.

La profesora Rosa Sanmartín Pérez nació en Valencia en 1974 y es, como acabo de decir, doctora en Filología Hispánica por aquella universidad. Es colaboradora en el servidor web de literatura española Parnaseo y coordinadora de la revista electrónica Stichomythia. Es coautora de diversas publicaciones, entre las que destacan Lineas actuales de investigación literaria, de 2004, ¿De qué se venga Don Mendo?: 
Teatro e intelectualidad en el primer tercio del siglo XX, también de 2004, y Campus stellae. Haciendo camino en la investigación literaria, de 2006. Ha publicado en diversas revistas y participado en numerosos congresos sobre literatura española.

La obra que pretendo enjuiciar consta de dos partes netamente diferenciadas: la primera es un estudio profundo y completo de toda la teoría dramática de los Machado y en particular del conocido como Manifiesto teatral de ambos hermanos (1928-1941), que constituye a mi juicio el trabajo más completo que conozco sobre este asunto y que pone en claro una serie de datos que hasta ahora desconocíamos. Evidentemente, la prensa fue receptora de toda la teoría teatral de los Machado, tanto de Antonio como de Manuel. Este último fue, como es sabido, crítico profesional en ejercicio primero en El Liberal y luego en La Libertad; y Antonio, aunque no de manera tan asidua, fue publicando trabajos sobre teatro, que comienzan sin duda por un estudio de gran interés y al cabo de mayor trascendencia. Se trata del artículo Sobre el porvenir del teatro, publicado por primera vez en Segovia, en abril de 1928, en la revista Manantial y, unos días más tarde, el 27 del mismo mes, en la revista La Libertad. Este texto, que constituye la base del conocido hoy como Manifiesto, aparece, pues, publicado bajo la firma del menor de los hermanos, aunque luego se reconoce como depositario de la ideología de ambos acerca del teatro.

El trabajo de Rosa Sanmartín nos permite adentrarnos con toda suerte de detalles en el estudio de este texto y en otro más, aparecido precisamente en abril de 1928, unos días antes del estreno de Las adelfas en el teatro Eldorado de Barcelona, en que vuelven a publicar un texto referido a la creación dramática de ambos, en esta ocasión firmado por los dos. Es un artículo que aparenta una reseña del estreno de Las adelfas, pero que en realidad reproduce una entrevista que uno de los redactores de La Noche y El Día Gráfico, Francisco Madrid, había realizado a ambos hermanos. Hay, pues, una comunidad interesada de opiniones sobre teatro, fruto sin duda de la entrañable relación de ambos, que les hizo compartir hasta el mismo hecho de editar, actualizar y comentar sus propias obras dramáticas. Este capítulo debe tener para nosotros un valor singular, porque por primera vez aclara una serie de puntos que habían sido objeto de discusión de todos los críticos que nos hemos acercado al teatro machadiano, comenzando por Miguel Pérez Ferrero, que en su conocida Vida de Antonio Machado y Manuel había tratado con rigor -creíamos- suficiente aspectos del mismo como para quedar claramente informados del Manifiesto, aunque, transcurrido ya tanto tiempo, se observa una serie de deficiencias que en el libro de Rosa Sanmartín quedan definitivamente aclaradas.

Hay un segundo fragmento de este capítulo que merece particular elogio. Es el titulado La teoría teatral en su obra dramática, donde analiza y confirma cómo se va cumpliendo, adaptando y practicando toda esta teoría en su obra original, desde el primer drama (Desdichas de la fortuna o Julianillo Valcárcel, 1926) hasta el último (El hombre que murió en la guerra, 1941). En la primera obra ya se aprecia alguno de los rasgos más significativos de su teoría teatral, sobre todo cuando constatan y confirman por vía práctica que el teatro es un arte de tradición y de frutos tardíos, como decía Pidal, lo cual les lleva a tomar como modelo dramático lo más acendrado y novedoso 
de nuestro Siglo de Oro, ya que el drama se ambienta en la corte de Felipe IV y enfoca desde nueva perspectiva la historia del bastardo del Conde-Duque Julianillo Valcárcel.

El otro capítulo que nos merece particular atención y valoración es el referido a la última obra teatral de los Machado: El hombre que murió la guerra, estrenada en 1941, puesto que Las tardes de la Moncloa o las brujas de Don Francisco, La diosa razón y El loco amor son tres obras de las que tenemos diferentes noticias pero que nunca llegaron a representarse. El análisis de la profesora Sanmartín de esa última pieza representada nos parece de particular rigor y que supera con mucho los anteriores estudios sobre la misma, que han sido por cierto muy abundantes, hasta el punto de ser la que mayor número ha concitado en su torno, ya que la mayor parte de los estudiosos del teatro machadiano, comenzando por Miguel Ángel Baamonde, Jordi Doménech, Fatma Benhamamouche, etc., etc. hemos dedicado nuestra atención preferente a esta obra, atractiva como pocas en la dramaturgia del siglo XX. Tan significativa, distinta y sugerente es que ha venido despertando la atención de todos nosotros, que volvemos a ella una y otra vez; en mi caso desde 1971, en que le dedicaba ya un amplísimo capítulo (páginas 500 a 566) que el tribunal, presidido por Orozco, destacó sobremanera y que no he dejado de atenderla en los últimos cuarenta años, como hemos hecho todos cuantos nos acercamos al teatro machadiano, en especial Miguel Ángel Baamonde Hermida, que le dedicó casi todo su espléndido libro $\mathrm{La}$ vocación teatral de Antonio Machado (Madrid, Gredos, 1976). De estos reiterados trabajos puede verse un completo resumen en nuestro estudio introductorio a la edición de dicha obra, publicada conjuntamente con El aguilucho, de Edmond Rostand, en la Colección Austral de Espasa Calpe, Madrid, 2008. Pues bien, el trabajo de la profesora Sanmartín rehace y reformula en parte la opinión que defendía en su tesis doctoral, donde hablaba abiertamente de dos diferentes versiones de esta obra; una primera en dos actos, presentada a la censura bajo el nombre de Antonio Machado, y una segunda versión, en cuatro actos, añadida y firmada ahora por ambos hermanos. El libro que comentamos matiza en parte sus opiniones anteriores respecto a la autoría, que casi todos creíamos exclusiva de Antonio, pero queda clara la existencia de ambas versiones, aunque al final hayamos de concluir con la profesora Sanmartín que se trata de una obra también en colaboración, como todo el teatro suscrito por ambos. Queda clara, tras el pertinente estudio, la opinión de la autora, que le lleva a concluir que la obra se terminó de escribir en 1935 y que fue realizada en dos momentos bien diferenciados; el primero en 1929, en el cual quedarían concluidos los dos primeros actos, con temática bastante diferente al tercero y cuarto. De hecho -dice- a posteriori aparece un cuaderno de hule negro en el que se incluyen los actos tercero y cuarto de forma independiente de los anteriores, aunque a continuación de éstos, lo que viene a confirmar la sospecha -ya a casi certidumbre- de ambas versiones.

En opinión de la autora, perfectamente suscribible, los hermanos Machado innovaron y renovaron la escena española de su tiempo, aunque ello haya pasado desapercibido para la crítica posterior, que ha prestado atención a las nuevas corrientes teatrales del primer tercio del siglo XX y no ha terminado de entender el valor del teatro machadiano, que se esforzó por la recuperación de nuestra dramaturgia del Siglo de 
Oro, particularmente de Lope, coincidiendo con lo que opinábamos hace tantos años, cuando ya dedicamos un capítulo completo a la inserción del teatro machadiano en nuestra dramaturgia clásica; que produjo un nuevo tratamiento del Don Juan literario; que introdujo la psicología freudiana o la búsqueda del otro, temas -como dice- bien dibujados en la dramaturgia machadiana, en la que se unen tradición y leyenda, lo clásico y lo moderno y que consigue el logro personal de La Lola se va a los puertos, retrato de la cultura popular tan arraigada en ambos hermanos desde la infancia, y que se cierra con El hombre que murió la guerra, última del ciclo, de un amplio círculo que comenzó quince años atrás con Las adelfas. Rosa Sanmartín une estas dos obras porque, como puede comprobarse a lo largo de su estudio, ya estaba en la mente de los autores a la altura de 1928 la creación de esta última pieza, precisamente mientras la escribían, de la cual forma una especie de epígono, dato decisivo para entender el teatro de los Machado. Decía Manuel en una de sus crónicas que a pocos se les había ocurrido pensar que uno de los medios más eficaces para conjurar toda crisis comercial estriba en mejorar la mercancía, en dar buen género y en darlo barato, y que cuando tal sucede se produce inexorablemente el éxito, como sucedía cuando cantaba Fleta en el regio coliseo y éste se llenaba pese a lo elevado de los precios o cuando Lola Membrives representaba en el Lara, rebosante siempre de público, costase lo que costase. Por eso los Machado, cuando suben sus obras a la escena, lo hacen con las mejores compañías: María Guerrero, Lola Membrives, Irene López Heredia y con el mejor género: toda una tradición popular folclórica, que les viene desde la figura paterna, el primer folclorista, Demófilo, que ellos convertirán en dramática renovadora, en la que quedaron plasmadas las teorías teatrales de ambos autores y la necesidad de una regeneración teatral, tan comentada en el ámbito escénico de aquellos años.

Pero en la dramaturgia machadiana -concluye Rosa Sanmartín- "hay algo más de original y es el hecho de que los hermanos Machado hagan confluir historia y leyenda, tradición y modernidad. Los Machado, buenos conocedores de la tradición popular -de la que Manuel fue fiel reflejo en sus composiciones poéticas-, emplearon esta característica para crear obras nuevas; en ellas, la leyenda y la historia se mezclan con rasgos característicos de principios de siglo como el individualismo, las teorías freudianas, el subconsciente, la mujer la crítica burguesa...". La única excepción, pese a la abundancia de estudios y las dificultades de su interpretación, será El hombre que murió en la guerra, que ha sido estudiada con más ahínco que cualquiera otra de sus producciones.

La pregunta que formula y nos formulamos todos es la de siempre: ¿por qué esta falta de interés general por el teatro de los Machado? Está claro que todavía la obra dramática de ambos no ha alcanzado la altura de sus respectivas obras líricas; pero lo mismo sucedió con Valle-Inclán, del que hace cincuenta años nadie conocía nada de su obra teatral y ahora es uno de los grandes dramaturgos del siglo XX. Debemos creer, además, que este olvido se debe a la repercusión histórica de la figura de Antonio Machado o sencillamente a implicaciones políticas que no hay por qué recordar.

Ya en 1970 hablábamos por extenso de que se hacía necesario rescatar del oscuro fondo a los Machado y su teatro. Esto mismo se sigue pretendiendo a la altura de 2010. 
“Devolver- dice Rosa Sanmartín- si no a la escena española, sí a la memoria, una faceta de la historia del teatro poco recordada. Faceta que, azarosamente -añade ella- un poco como empezamos este trabajo, no llevó a descubrir, ya no en la prensa sino entre la censura que tanto daño hizo a la dramática de aquella época, un manuscrito de Antonio Machado que contenía la versión primera de El hombre que murió la guerra". Decía José Bergamín -apostilla- en un trabajo de 1975 que las cosas que no pasan deben valer para siempre y entre ellas habrá que citar a ambos hermanos, siempre inseparables en su creación dramática, por muy diferentes caminos que tomarán uno y otro. El unir ambos caminos para recobrar una creación conjunta ha sido la misión de este trabajo, que a nosotros nos ha agradado particularmente. La bibliografía que reúne es la mejor seleccionada y la más completa que hasta estos momentos se ha compuesto y recopilado, valga la paradoja; la mejor y más añadida, como se decía antes, del teatro machadiano.

Las mínimas deficiencias formales que encontramos en el estudio en nada empecen el valor del libro, porque hoy son ya tan frecuentes, que han quedado como asidero de viejos cascarrabias, que no transigimos todavía y nos resistimos como podemos con "la modernidad idiomática" que nos imponen las circunstancias y contra la que en balde nos rebelamos. Las cosas son como son y no como uno quiere que sean. Apenas vale la pena citar: algunas comas de más, algún anacoluto y alguna expresión no enteramente castellana, que son fruto o del tiempo que pasa o de nuestra incompetencia para enseñar a escribir incluso a los mejores alumnos. Por lo demás, el estudio constituye una interesante y más que valiosa aportación a un asunto que viene ocupando ya a muchos investigadores y cuyo comienzo por nuestra parte, recordado ahora con nostalgia, se remonta exactamente a cuarenta años atrás, en el otoño de 1970.

Dámaso Chicharro 



\section{Pedro A. González Moreno, Anaqueles sin dueño, Madrid, Hiperión, 2010, 88 pp.}

Se echa de menos, en este nuevo libro de Pedro A. González Moreno, que no se especifique en la dedicatoria inicial quiénes son Pedro José y Enrique Moreno y por qué es pertinente dedicarles estos poemas. Creo que en este libro, además de una dedicatoria, es necesaria una advertencia para "espantar" a dos tipos de lectores de potencial igualmente nocivo: el "sensacionalista" y el "culturalista" que busque el dato erudito sin prestarse al esfuerzo de ahondar en la realidad humana que lo origina.

Revelando quiénes son los citados se revela de entrada que esta no es lírica libresca (que puede ser, por otra parte, tan digna como cualquier otra), que si el poeta ha elegido el tema del suicidio es porque se corresponde con su fondo vital más sangrante y hondamente sentido y le servirá, ante todo, para profundizar en viejas obsesiones que han ido tomando forma en libros anteriores (la muerte, el paso del tiempo, el arraigo en la afectividad que intenta salvarlos, y la poesía como posicionamiento ético y vital ante esa incertidumbre).

En cuanto al contenido de la obra, digamos primero lo más importante: Anaqueles sin dueño es un tratado sobre la piedad: lo que, si faltaran otros méritos, lo convertiría de entrada en un libro digno, sobre todo porque no se resigna a ser conciencia propia, delicadeza individual, sino que aspira a crecer en los otros y a crear en el lector una necesidad de empatía. Esta llamada ininterrumpida a la conmiseración es el eje del libro y la clave que nos permite interpretar la gran cantidad de prismas desde los que se afronta el hecho del suicidio.

Prismas como, por ejemplo, que el acto "luctuoso" reciba una intensa poetización que lo salva de su sordidez (la muerte de Goytisolo en El salto es casi éxtasis o rapto místico); que se apele a la comprensión del dolor íntimo del asesino de sí mismo; que el suicidio se justifique como un acto estético (De la turbia belleza), ético (destinado a salvaguardar la vida de su tránsito a la indignidad -como ya nos instruyó Séneca-, en El ruido de un sable o Sólo deriva), y hasta como un acto epistemológico que, en Orillas del Ouse, da una sugestiva vuelta de tuerca a un tema tan hecho lugar común como el suicidio de Virginia Woolf:

\footnotetext{
“¿Cómo será la última mirada desde dentro del agua? ¿Cómo el último brillo, ya sin color, de la materia, la levedad de un cuerpo que va hundiéndose..."
}

Prismas como el que eleva al suicida a la categoría de símbolo de la condición humana (Con nombre de erosión); o bien que (como sucede en Desde los terraplenes del insomnio y Calendario roto), se imponga cierta esperanza con la presentación de un mundo sensible hacia quien va a morir (los puentes de París sobrecogidos por la desaparición de Celan); o que se reivindique el auténtico (aunque frágil) amor a la vida de estos poetas, mostrando las últimas oportunidades que son capaces de concederle 
a la existencia antes de arrancársela; o que, finalmente, se presente el sucidio como un acto tan "fácil" que parece casi exigido por la propia inercia del vivir (Una llama en el agua).

Un poema excelente como Último amanecer, sobre Sylvia Plath, serviría como síntesis de todo lo anterior: la muerte en una mañana de sol como "antídoto" al tono lúgubre esperable, la directa implicación del autor, el último acto de amor inútil de dejar preparado el desayuno a los niños..., sencillamente impresionante. Las muescas de pura humanidad son tantas, y tan brillantemente defendidas, que la posible indolencia y cinismo del autor quedan sin cobijo posible y no tienen más remedio que firmar su rendición.

Junto a lo comentado, el lector atento y mínimamente versado en la poesía del autor encontrará múltiples guiños a su mundo creativo, ya sea a nivel de ideas (la manifestación de la decepción ante un oficio poético que es pura ortopedia de la vida que no se ha sabido reproducir, en Formas de la negación y La noche del visionario); o ya sea al nivel de simples imágenes (por ejemplo, en la descripción del interior de Costafreda como un caserón desolado - en Danza de fantasmas-; tampoco podía faltar un “desván (...) con su olor a baúles, con su danza de sombras/ y su lenta deriva/ de cosas muertas...).

En cuanto a técnicas compositivas, es necesario comentar estrategias tan hábiles como la creación de poemas a partir de versos suministrados por los autores que se retrata, con lo que se consigue, por lo menos, estas dos certeras dianas: en primer lugar, la generosidad de permitir a los poetas participar de su propio epitafio, y en segundo lugar dotar al libro de una densa atmósfera dramática de "continuación" de la obra poética que decidieron abortar, cuyas fisuras va completando el autor con un poso de tristeza impotente. $Y$, al igual que ocurre en los poemas de la breve breve plaquette del autor titulada Dodecaedro, son frecuentes los casos de "contagio", es decir, que la semblanza de un determinado poeta lleve implícita la asimilación de sus señas de identidad creativas: Así, en Instrucciones para no perderse dentro de un sueño, el versículo, los elementos irracionales y oníricos o la concepción del poeta como "visionario", se ajustan al retrato de un surrealista; o en La rosa nueva, los elementos de vanguardia lúdica, pero traspasada de compromiso social, se ajustan al de Maïakovsky.

Consignar finalmente que, una vez más, la estructura del libro vuelve a ser la más sabia: antes de la sucesión de baldas y autores malogrados, el Prólogo ha introducido el sobrecogimiento que aguarda al lector con la presentación de esa librería como un organismo "vivo" a costa del desgarro nunca salvable de quienes la pueblan. Los poemas Estantería y Anaqueles sin dueño, que alguien podría rechazar como simple reiteración de lo que va a exponerse, quedan justificados en la posición introductoria que ocupan (son anticipo, no repetición) y en la altura emocional de su imaginería:

“están todos

los que bebieron sed y nunca se saciaron, 


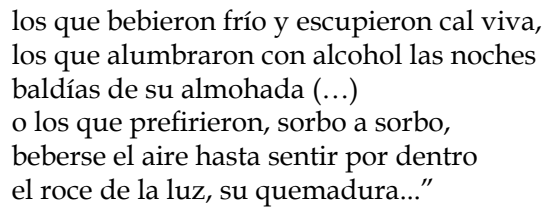

Y el Epílogo se hace depositario del hermanamiento emocional mostrado durante todo el libro con la decisión del poeta de enraizarse en esos muertos pese a la hipotética perturbación que aporten a su vida, gesto que, sencillamente, los reintegra de nuevo entre los aún vivos: "Al llegar cada tarde, cuando vuelvo del mundo,/ salen a recibirme con sus manos, aún tibias/ que nunca se acostumbran a morirse del todo; y a veces me preguntan/ cómo sigue la vida por la calle,/ si la avena está alta o si germina/ el último poema que dejaron escrito..."

Un último escalofrío para uno de los pocos libros auténticamente redondos (en contenido, forma y estructura) que nos ha regalado la última poesía española.

Rafael Escobar Sánchez 

Javier Sánchez Zapatero, Escribir el horror. Literatura y campos de concentración, Barcelona, Montesinos, 2010, 205 pp.

En Escribir el horror. Literatura y campos de concentración, Javier Sánchez Zapatero construye un ensayo que supone un acercamiento responsable a una realidad controvertida que ha marcado la historia reciente. Esta aproximación al fenómeno concentracionario -concebido de forma universal- se vertebra a través del análisis -de naturaleza comparatista- de distintos textos que constituyen algunos de los testimonios más significativos de aquellos que sobrevivieron a campos de concentración como los de Auschwitz, Djelfa o el Gulag soviético. El corpus textual es conceptualizado por Sánchez Zapatero como el testimonio directo, de naturaleza necesaria y catártica, que contribuye a la recuperación de la memoria histórica, silenciada desde el primer momento, en el caso de los campos de concentración. Lo que pretende el autor es, en última instancia, "analizar de manera conjunta los testimonios de quienes volvieron para contarlo". Estos hombres y mujeres, como se señala en el libro, son víctimas y testigos directos de lo que se ha llamado "el fracaso de la razón" en el siglo XX, y están legitimados para hacer un uso pedagógico de la memoria, reescribiendo una parte de la historia marcada por la violencia extrema y la intolerancia.

El marco teórico desde el que Sánchez Zapatero aborda el estudio de la literatura de los campos de concentración es el perteneciente a la teoría de la literatura y literatura comparada. De este modo, el autor se enfrenta a la contemporaneidad e interculturalidad del fenómeno, partiendo de los presupuestos teóricos que convierten la producción literaria de Max Aub, Primo Levi, Jorge Semprún, Imre Kertész o Varlam Shalamov -entre otros-en, además de testimonios directos del pasado, manifestaciones artísticas y, por lo tanto, estéticas. No obstante, Javier Sánchez Zapatero ha de enfrentarse también a cuestiones conceptuales como el propio término "campo de concentración" y sus rasgos comunes o divergentes con respecto a otras realidades caracterizadas por la privación de la libertad -como las cárceles o los hospitales- o a la expresión de lo inefable, esto es, la necesidad de un nuevo lenguaje que dé cuenta del horror sin precedentes que supuso la realidad concentracionaria. Tomando este punto de partida, el autor analiza los diversos testimonios, poniéndolos en relación con las distintas actitudes con las que los supervivientes han afrontado la narración de sus experiencias extremas. Desde un tipo de escritura caracterizado por una prosa sobria, a la estilización de la peripecia vivida para convertirla en ficción literaria, pasando por el silencio como única vía operativa -alegórica-, dada la inconmensurabilidad de los campos.

La concepción del espacio concentracionario reconstruido por las distintas manifestaciones literarias encuentra características comunes que el autor analiza de un modo sistemático. En este sentido, el campo de concentración es concebido como un espacio único, apartado del mundo y caracterizado por la incógnita. La aniquilación 
de la esencia humana, puesta de manifiesto en la anulación de la persona -sin nombre y sin pertenencias- es otro rasgo definitorio y común a estos textos. En esta línea, la animalización, incapacidad de los recluidos para reconocerse como seres humanos, o la dificultad de los supervivientes para convivir con sus semejantes, incide en la huella que una experiencia tan dramática dejó en los que han decidido contar su paso por un campo de concentración y/o exterminio. Del mismo modo, el peso de la culpa, manifestado a través del sentimiento angustioso de estar vivos, pone de relieve la necesidad de narrar lo vivido para intentar comprenderlo.

Se trata, pues, segúnSánchez Zapatero, de establecer un diálogo entrelas distintas obras de los supervivientes -como si de una estructura de "vidas cruzadas se tratase", estudiándolas como manifestaciones concretas de un fenómeno universal de naturaleza heterogénea, debido a que todos los campos de concentración comparten una serie de rasgos comunes pero son, a la vez, diferentes entre sí. Este ensayo proporciona un marco teórico general para enfrentarse a textos de índole concentracionaria, y lo hace desde la rigurosidad y claridad expositivas. Javier Sánchez Zapatero ha confeccionado un interesante texto caracterizado por su afán esclarecedor y divulgativo.

Javier Voces Fernández 


\section{Elena Vega-Sampayo, La poesía esencial de José Corredor-Matheos, León, Universi- dad de León, 2008, 572 pp.}

Que José Corredor Matheos es uno de los poetas más destacados de su generación -además de crítico de arte, traductor o antólogo- es, quizás, tópico recordarlo a estas alturas, pero no por ello menos necesario. Como tampoco deja de serlo el añadir que, de entre esos mismos poetas ha sido uno de los que mejor ha sabido reinventarse, salir del encasillamiento al que antologías, críticos o, incluso, lectores, han tendido a relegarlos, a lo que ha contribuido - ¿para qué negarlo?- en buena medida la propia producción de muchos de ellos. Sin embargo, en el caso de Corredor Matheos, como en el de Ángel Crespo, Jesús Lizano, Enrique Badosa, Lorenzo Gomis o Gabino-Alejandro Carriedo, por citar algunos, encontramos una obra que ha sabido renovarse con el tiempo, o, mejor dicho, que ha conseguido permanecer viva, palpitante, adquiriendo esa condición de intemporalidad o universalidad tan poco frecuente en un autor contemporáneo y, mucho menos, en un autor vivo. A ello ha contribuido no sólo la lúcida elección de los temas abordados, que huyen de la rigidez a que obligaba aquella poesía del medio siglo vinculada a lo social y tan del gusto de su generación, sino también un uso de las formas, sean estas tradicionales o no, muy personal. Podríamos apuntar ya que una de las características definitorias y singulares de su quehacer poético será el hecho de que en su obra forma y contenido nazcan de una visión de la poesía marcada por el despojamiento y la levedad propios de las culturas orientales, de los místicos o de poetas que tuvieron como objetivo -y obsesión- un ideal de pureza en ocasiones inalcanzable, tal es el caso de Juan Ramón Jiménez, de Rainer Maria Rilke o del norteamericano William Carlos Williams.

El amplio estudio que aquí comentamos, realizado por Elena Vega-Sampayo, ayuda en buena medida a desbrozar el bosque corredoriano, a acercar al profano, a orientar al aficionado a su poesía y a profundizar, sobre todo en lo tocante a algunos aspectos insólitos de la misma, al estudioso y conocedor de su obra. Por ello, y sirva como ejemplo, uno de las intereses de este estudio consiste en abarcar la producción del poeta hasta el momento actual, lo que implica vislumbrar, junto a las tres etapas tradicionalmente señaladas por la crítica a la hora de clasificar su producción ("poesía de la vida cotidiana", hasta 1960; "poesía de la existencia", hasta 1971; y "poesía del despojamiento", a partir de Carta a Li-Po y hasta El don de la ignorancia, en 2004), la existencia, nos dirá la propia autora, de "una cuarta etapa a la que también parecen adscribirse poemas escritos con posterioridad a este título". También es destacable la pretensión de "apuntar cierto cruce de tendencias observable más allá del proceso de asimilación y aprovechamiento progresivos que se lleva a cabo en la trayectoria corredoriana de los cuatro libros publicados de 1975 a 2004 [Carta a Li-Po (1975), Y tu poema empieza (1987), Jardín de arena (1994) y El don de la ignorancia (2004)] y que traza 
una ineludible raya secuencial" que precisa los núcleos fundamentales de una obra, como la del manchego, densa y no siempre fácil, pese a su aparente levedad.

La organización del material que constituye este trabajo, fruto de una tesis doctoral dirigida por el profesor José María Balcells, es clara y precisa. Tras recorrer brevemente algunas de las claves de la biografía de Corredor-Matheos que puedan ser de utilidad para el estudio de su obra, la autora analiza su trayectoria poética y las etapas que la constituyen en lo que ella misma denomina un "estudio diacrónico de su creación poética". Sirve ello como pretexto para mostrar un primer acercamiento a las constantes de su lírica, a los puntos cardinales sobre los que se orienta el grueso de una producción no excesivamente extensa, pero no por ello menos compleja.

A continuación se estudia la teoría poética del autor, a la que casi debería denominarse teoría "artística", pues se analiza su visión de la poesía, pero también del arte en general a través de sus escritos, tanto los que conciernen a su propia obra, como sus textos críticos sobre otros poetas, en su mayoría coetáneos, sin olvidar -no podía ser de otro modo- algunos procedentes de su amplia labor como crítico de arte. A través del estudio de estos textos, podemos vislumbrar ya algunas de las constantes citadas en el sucinto análisis de sus libros y que nos irán preparando para el grueso de este estudio, sirviendo claramente de base para la materia de los capítulos siguientes, verdadero núcleo analítico.

Podría hablarse así, de tres conceptos fundamentales sobre los cuales, según la autora, se sustenta la producción del autor de Carta a Li-Po: la trascendencia, el silencio y la esencialidad. Para completar estas primeras conclusiones, se realiza también un breve recorrido por buena parte de los recursos más caros al poeta en esa constante búsqueda de lo esencial, así como por sus símbolos más habituales, las abundantes antítesis y paradojas que recorren sobre todo su producción más orientalista y su peculiar uso de algunos tropos como la metáfora. Una utilización que resulta original y novedosa, pues, a través de su desnudez, su poesía se desliga en cierta medida de la costumbre, arraigada en la tradición literaria occidental, que suele destacar tal vez en exceso su alta carga cognitiva y expresiva. La presencia de un constante simbolismo servirá al poeta también para rechazar "el intelectualismo, el voluntarismo y el utilitarismo como elementos definitorios de la poesía".

Las influencias extremo-orientales y otras, citadas más arriba, son diseccionadas en el capítulo siguiente, "Resonancias". Influencias que, como el budismo zen, el taoísmo o el sufismo y la obra del poeta medieval persa Omar Jayyam han permitido esa evolución y asimilación de culturas que hacen del despojamiento, al que CorredorMatheos aspira en su palabra poética, un caso único y singular en nuestra lírica, por su asimilación plena -que no imitación- de las culturas de Oriente. No hay una pretensión esteticista de crear una lírica "orientalizante", sino una búsqueda de respuestas, de conocimiento y profundización a través de la poesía, que encuentra su camino en la visión de mundo de las filosofías orientales. También se recorren, en el capítulo siguiente, aquellos aspectos de la métrica empleada por el poeta que resultan más relevantes, desde el versolibrismo hasta el uso de dos composiciones muy comunes, 
pero paradigmáticas de las dos tradiciones culturales representadas en su obra, esto es, el soneto -tradición occidental- y el haiku -oriental.

En el recorrido por sus libros se dice también que el misterio y la magia de lo cotidiano estarán muy presentes en los primeros textos del poeta, Ocasión donde amarte (1953) o Ahora mismo (1960), proyectándose transversalmente hacia el conjunto de su producción posterior, algo que ya se percibe en la misma elección del léxico y de los campos semánticos. Es preciso señalar aquí el influjo de la memoria, "no el recuerdo", precisa la autora, como cómplice y reveladora de esos objetos, esas "cosas" que nutren la vida diaria, con las que el poeta se identifica al incorporarlas al texto con un singular afán de inventariar la realidad cotidiana y la sencillez de la vida. También de revelarlas en su íntima esencia primordial.

Además el tiempo y el espacio establecerán una lucha dialéctica continua en la obra del manchego. Sobre todo el primero, cuya presencia es más que palpable en el gusto por lo crepuscular como símbolo de retorno a lo esencial. La presencia del tiempo y la preocupación por su huida se perciben abundantemente en los títulos de sus obras. Sin embargo, ambos, tiempo y espacio, deberán ser trascendidos hasta alcanzar el vacío absoluto y necesario. El tiempo "como valor negativo -doloroso, olvido, aniquilador, inclemente- se enfrenta a la nada como valor positivo -con infinita potencialidad y exento de tensiones, olvido balsámico, una nada opuesta al vacío existencial que parecía dictado por el tiempo". Así se incorpora el concepto de la nada y el vacío positivo, conceptos provenientes de las filosofías extremorientales, que suavizan, casi podría decirse que anulan, ese conflicto. La nada, plasmada en la levedad significativa y en la desnudez expresiva, será el fruto de su búsqueda estética y transcendente del valor de la belleza y de la totalidad del mundo. Su hallazgo de lo esencial, y ahí radica su diferencia más importante con los místicos, no está en la divinidad, sino en el concepto del vacío, del mismo modo que para el sufismo, el budismo o el taoísmo. De esta visión de la nada "entendida como espacio sin límites" surgirán otros dos conceptos que irán cobrando mayor protagonismo en la última poesía corredoriana, la ignorancia y la extrañeza.

Dentro de esa confrontación entre el tiempo y la nada, la "mirada" elegida por el escritor vendrá a sintetizar ambos al mostrar diferentes puntos de vista: "la incorporación de la mirada del lector, la conformidad con lo contemplado, la autocontemplación, la reversibilidad de la mirada, el desdoblamiento, la direccionalidad del mirar, la ventana y la terraza como lugares privilegiados desde donde la mirada opera, la mirada en movimiento" ... Todo ello hace que Corredor-Matheos sea el vate cuya obra se acerque, más que la de ninguno de sus contemporáneos, a lo contemplativo, pues "la mirada permite al poeta estar, a la vez, dentro y fuera del objeto observado". Esa mirada desposeída le servirá así como instrumento de conocimiento trascendente y como vía para alcanzar la nada, el vacío absoluto. La mirada resulta un retorno a sí mismo, pero también su máximo baluarte en la búsqueda del conocimiento pleno.

La Naturaleza y la comunión, incluso la fusión, con ella se encuentran al final del camino existencial de preocupación por el destino del hombre, pues a través de ella 
accede también a lo trascendente. Además le servirán para cuestionar la autonomía de la producción intelectual, buscando restituir esa armonía primigenia entre el mundo y el conocimiento. La acción reflexiva y contemplativa, envuelta en el marco natural, "alberga frecuentemente", nos dice la autora, "una semilla de felicidad: el contacto con la naturaleza se contempla como una reconfortante comunión sensorial".

Resulta especialmente significativo el apartado dedicado a los "metapoemas", por su importante presencia dentro de todas las etapas creativas del poeta. Con ellos se va creando un continuum que atraviesa toda su producción y en el que la reflexión sobre el acto creativo o la relevancia del silencio serían el eje central. El yo poético se disuelve en su obra, se funde con ella y con la naturaleza, integrándose en un todo sin límites. De ahí la importancia, ya aludida, de la ignorancia como verdadera sabiduría, pues, nos dice Vega-Sampayo, "saber es ignorar".

Dada la importancia de la reflexión sobre el arte y lo artístico en la trayectoria poética y profesional del manchego, se hace imprescindible el apartado final dedicado a la vinculación entre poesía y fotografía o pintura. Esa confluencia de expresiones extraídas del mundo del arte estará muy presente en algunos poemas muy concretos del grueso de su producción, tanto en los que abundan en referencias paisajísticas de naturaleza pictórica, como en aquellos otros dedicados a la contemplación del poeta de una obra artística, pues "la producción artística -poética, pictórica- le da pie a reflexionar no sólo sobre la misma, sino sobre la propia identidad del yo poético y su integración o separación respecto del objeto".

Este libro, que, por su amplia documentación y sus lúcidas reflexiones, resulta muy útil para acercarse a la poesía de Corredor-Matheos, se cierra, como suele ser común en estos casos, con una bibliografía, tanto de la obra lírica del autor, como de sus traducciones, su prosa, una selección de sus libros en colaboración, ensayos, ediciones; además, claro está, de la bibliografía sobre el poeta y una densa bibliografía general.

Mario Paz González 


\section{Concepción Cabrillana Leal, Consideración sintáctico-semántica de esse. Un estudio a través de la prosa de Livio, Santiago de Compostela, Universidade, Lalia series maior 23, 2010, $138 \mathrm{pp}$.}

Decir sintaxis latina es evocar la referencia de una larga historia de estudios gramaticales. El enfoque de estos estudios ha ido descubriendo misterios del lenguaje y de la comunicación que han podido ser descritos de manera objetiva, aunque incompleta. Esta característica no deriva solamente del observador, pues es difícil hacer conscientes tantos mecanismos sin dejar algún cabo suelto para que otros lo anuden. Se trata de un ejercicio de abstracción de las tendencias que condicionan la disposición de la secuencia verbal en el discurso. Esta disposición se va definiendo en estructuras repetidas que de manera consciente o inconsciente permiten la generación inteligible de mensajes. Pero el reconocimiento de una repetición sistemática no supone en absoluto una regularidad perfecta, entre otros motivos, por la interdependencia entre los niveles en que se articula el lenguaje. Por eso la información que no está claramente definida en el nivel fonemático o en el morfológico, o en el sintáctico, se completa con la que aportan las diferencias semánticas que se insertan en esos niveles distintos. También la disposición sintáctica depende en cierta medida de esas noticias semánticas, o más bien cuenta con ellas. De ahí la "consideración sintáctico-semántica". Y de ahí también que la autora, teniendo en cuenta los estudios precedentes, se anime a hacer una "consideración" corroborada por un análisis de la frecuencia con que se repiten las estructuras en un texto amplio y de variada temática como es la historia de Livio.

El estudio ponderado de ciertas disposiciones y caracteres semánticos se presenta en una gradación de límites desde menor a mayor relevancia semántica del verbo y de las demás clases de palabras que constituyen el discurso. La orientación metodológica de esta monografía se anuncia desde las primeras páginas. El tema tenía raíces muy antiguas en la especulación filosófica sobre el lenguaje, y aún mantiene su interés para la lingüística general, porque analiza uno de los rasgos estructurales más característicos de las lenguas europeas. El método con que se efectúa este análisis desarrolla la línea de investigación seguida por la Gramática Funcional en la Escuela de Ámsterdam específicamente para el latín. Este modo de acceso al comportamiento sintáctico del verbo esse se funda en el razonamiento sobre la formalización de las posiciones y relaciones verbales en la configuración de la frase al servicio de nociones significativas en marcos predicativos. Estos marcos contribuyen decisivamentea facilitar la clasificación de los usos de acuerdo con las nociones semánticas fundamentales. Este instrumento de descripción añade un valor importante a este trabajo. Se recoge de modo ordenado en cada capítulo cuando se revisa consecuentemente el esquema que se puede asignar a cada estructura, habida cuenta de los ejemplos comentados y de las opiniones recogidas. Los esquemas estructurales más representativos mantienen una referencia abreviada a través de la discusión de los aspectos más relevantes. 
Destaquemos la novedosa interpretación mediante el análisis de la formalización semántica de la construcción atributiva latina, de la sintaxis del dativo, del genitivo y la designación existencial-locativa.

Un complemento interesante de esta descripción del funcionamiento sintáctico de esse es la figura contrapuesta de los verbos asociados por la evolución de la lengua latina, vigentes aún en nuestras lenguas romances. En efecto, a pesar de que la teoría sintáctica pretende la formalización de las descripciones lingüísticas, estas formas no existen despojadas de su materia, fuera de una lengua concreta. Por eso, toda descripción, si se desea precisa, y por muy formal que se quiera, adquiere mayor propiedad si cuenta con una correspondencia con otra lengua o lenguas. Ahora bien, el latín ha sido estudiado por hablantes de lenguas romances y por los que tienen una lengua materna diferente al ámbito románico, y esta múltiple perspectiva, con ocasionales coincidencias, ofrece todavía un aspecto más ajustado. Así lo procuraba la autora en su discusión de las definiciones y acuerdos entre los gramáticos que escriben en diferentes lenguas.

La conexión significativa entre el nivel sintáctico y el semántico resulta notable en las estructuras características de este verbo con mayor motivo, pues la realización de una variedad de construcciones permite una variedad de usos en la expresión. En este aspecto, la crítica a la hipótesis de la cúpula-soporte evita incurrir en el exceso de atribuir la mayoría de las nociones a las estructuras focalizadas con el auxilio de este verbo. Por eso, la exposición se decanta por presentar gradualmente la extensión y complejidad que adoptaban en latín las estructuras con esse, al tiempo que se desgrana la capacidad de expresión semántica. Desde las construcciones monovalentes de existencia, se pasa por 'actuar como/llegar a ser' (en comparación con otros verbos como exsto, existo, euenio, uiuo). Para ilustración de esta especie de paradigma gradual se recurre al apoyo en la evolución seguida por otras lenguas y a la perspectiva pragmática, que muestra la contigüidad de estas dos construcciones en el uso de la lengua latina. Esta comparación se establece mediante los rasgos semánticos que caracterizan a los argumentos relacionados por la construcción (animado, definido, concreto, control, dinámico), en una gradual escala entre verbos predicacionalmente completos, semi- predicacionales y mínimamente predicacionales. En cambio, la discusión sobre la construcción con genitivo compromete la perspectiva de descripción, ya que la función del genitivo como instrumento sintáctico no admite paralelo ni semejanza. Entrarían en esta categoría las estructuras que expresan cualidad, las que expresan pertenencia a una clase y las que predican posesión, pero tal distinción depende fundamentalmente del referente que tenga la palabra en genitivo, interpretable en función de las distinciones semánticas reconocibles por los competentes en una lengua. En este análisis se destaca la formalización a manera de locuciones de grupos de palabras que se asocian por costumbre. La contigüidad semántica facio-fio-sum explicaría que el verbo esse y el verbo facere compartieran la posibilidad de construirse con genitivo.

En la recopilación final se remite a la macrofunción Adscriptivo para la consideración semántica de estas relaciones de cualidad, inclusión, pertenencia e identificación. Una mirada a los modos de vida de la comunidad que empleaba el latín sugieren a la autora la secuencia de los niveles en que se entiende la posesión (pp.75-76). 
Esta estructura en todo caso se clasifica en el nivel predicacional más bajo. La selección de un nombre en dativo justifica, según el parecer de la autora, la comparación entre el uso de sum+dativo, el datiuus iudicantis y lo que llama 'dativo regido' (cap. III. 4). Los adjetivos " cuyo contenido semántico se encuentra fundamentalmente en torno a ideas de afección (benevolencia, amistad, agrado, etc.) cercanía, igualdad, utilidad, disposicióninclinación o sus análogas y contrarias" (p. 83) parecen merecer una atención particular de la autora. A propósito del uso del dativo con sum, se procede a una clasificación semántica (cualquier nombre animado o inanimado puede construirse con un dativo y sum) y cuantitativa de los términos que participan en las dos estructuras. No obstante, se corrobora la utilidad de la macrofunción Indirecto propuesta por Lehmann con las funciones particulares de Receptor, Beneficiario o Experimentante que se asocian al rasgo humano de un nombre en dativo en situaciones de acción o proceso.

La atención a la sintaxis del llamado "dativus iudicantis" que selecciona sujetos abstractos completa este panorama de una parte de los usos con dativo. Estas estructuras se adscriben al nivel mínimamente predicacional. Pero la construcción de doble dativo se trata en correspondencia con la de dativo final. La estructura de dativo posesivo se diferencia del esse copulativo propio de esta manera de expresar la finalidad. A ello contribuye la tendencia a la formalización de locuciones. Cuando el dativo posesivo se considera, se distinguen posesiones inalienable, permanente, física, temporal (en el ejemplo, un sueldo) inanimada inalienable y posesión abstracta. Del examen de la frecuencia de todas ellas, se extrae la observación de una tendencia a que la inalienable y la abstracta especialicen esta forma sintáctica. Plenamente predicativo resulta a juicio de la autora la estructura que se identifica con la noción 'existir para alguien' respecto de la de doble dativo, que es mínimamente predicacional.

La exposición concluye con las estructuras que integran un elemento locativo. De esta manera se cierra el abanico por el extremo más tendente a la predicación. Se consideran dentro del uso predicativo del verbo esse en contraste con las construcciones existenciales. De todo ello resulta una descripción del modo en que las nociones expuestas tienen su desarrollo en latín bastante distinto de anteriores análisis estructurales, que pretendían un acceso más abstracto y menos semántico de las funciones sintácticas. La selección de un corpus extenso pero limitado en la obra de Livio facilita la evidencia de los resultados. Una laboriosa confección de cuadros con los datos ordenados conforme a las hipótesis propuestas eleva el valor de este estudio. El indicio que la estadística proporciona nos muestra las tendencias más generales a la formalización de las estructuras sintácticas. La elección de alguno de los libros y no de todos podría haber distorsionado la percepción dada la diversidad con que se distribuye el contenido, las descripciones, los relatos, los discursos. La aplicación del mismo método se ha observado en la exposición de los capítulos, para que esta apariencia ordenada facilite la comparación de los resultados. Con todo, el balance de resultados se recoge de otra manera en la recapitulación final, en la que se tienen en cuenta las comparaciones anteriores bajo un aspecto sintético. 



\section{Luis Unceta Gómez, La petición verbal en latín. Estudio léxico, semántico y pragmá- tico, Madrid, Ediciones Clásicas-Ediciones UAM, 2009, 242 pp.}

Describir el funcionamiento de una lengua es siempre difícil. La atención a un pequeño sector del sistema, gracias a la ingente labor desarrollada por la lingüística en el siglo XX, se amplía necesariamente en todas direcciones. Con mucha más razón, cuando se atiende a un núcleo de relaciones abstractas definidas por este grupo de verbos latinos. El objetivo al que se orientaba el estudioso de la lengua hace años en la descripción "desde dentro" de la lengua se ha ido ampliando. La teoría de los actos de habla ha mostrado el recurso de la lengua con que se adapta al contexto situacional y al uso adecuado en la comunicación. Ambas perspectivas se complementan. La perspectiva situacional se combina con la interna, en la que las palabras se distinguen por diferencias mínimas que se marcan en la forma y en la semántica.

De ahí que se comience el estudio en dirección opuesta a aquella en que progresa el título. En efecto, detrás de la explicación de los actos de habla en la petición y su trascendencia en la dimensión pragmática del uso de la lengua latina, llega al final la descripción del léxico. El acierto de esta aproximación a la forma de expresión latina se observa también en el tratamiento de distinciones que pueden ser problemáticas si se pretende delimitar el campo de estudio. El esquema básico de la comunicación que se expresa se compone de un emisor y uno o varios receptores que pueden tener entre ellos una diferencia social codificada en la distinción del léxico, de las construcciones sintácticas y de la entonación. Pero además el autor da comienzo a su exposición desde una posición aún más abstracta como es la volición y la intención comunicativa. Por eso la petición se enmarca en las funciones del lenguaje desiderativa e instrumental.

Desde la voluntad humana de condicionar la actuación de otros, la petición se relaciona con construcciones y vocabulario expresivos del mandato y de la inducción del encadenamiento controlado de las causas de un proceso o cambio. En este nivel tan general, el autor recoge de manera crítica y ajustada a su asunto las contribuciones eruditas más señaladas para definir los actos de habla directivos, así como el establecimiento de una cortesía que se materializa en la acuñación de ciertas características de lengua. Esta cortesía está en un plano diferente de la relación cuando el emisor se expresa y tiene un grado determinado de control sobre la realización efectiva de lo que ha manifestado, pero puede combinarse con la incertidumbre sobre la eficacia de la forma lingüística elegida.

De ahí la necesaria distinción de la modalidad de la lengua, deóntica, desiderativa o bien imperativa, que se articula con las variantes indicadas antes y la "combinación y mutua interferencia entre pregunta, consejo, orden o deseo" (p. 39). La distinción clara entre ellas se puede conseguir mediante un léxico especializado e inequívoco, pero la riqueza de matices que impone la convivencia se sirve a menudo 
de la indefinición para mitigar las susceptibilidades. Por eso la lengua debe ser capaz de permitir una cierta gradación de matices que se pueden difuminar todavía más en ciertas situaciones comunicativas. En consecuencia, quien ha asumido el objetivo de describir todo esto debe reparar en todas las que son significativas y pertinentes a la variedad real que el latín ofrece.

En ese aspecto, el presenteestudio no se pierdeenjustificar las posibles situaciones de uso, sino que se atiene a los medios concretos que la lengua latina ha desarrollado, tanto en el plano gramatical como en el léxico, partiendo de una relevancia semántica en esas estructuras. Se compara entonces la forma de los enunciados imperativos en latín, su caracterización del control y del agente, el empleo de los modos del paradigma morfosintáctico con la directividad en el plano léxico. Queda patente la imposibilidad de una caracterización unívoca de las formas de un mismo paradigma de acuerdo con estas funciones del lenguaje.

Algunas formas se prestan mejor que otras a la expresión de las notas semánticas que atañen a los modos del enunciado. La regularidad de los paradigmas aglutina y relaciona usos funcionalmente distintos. Por eso tampoco es de extrañar que el léxico desiderativo pueda tener usos directivos o al contrario. Aún más flexible ha de ser la estructura interrogativa, por tener menor caracterización formal exclusiva, y por eso se aplica también a prestar su indeterminación en esa escala gradual de matices que mencionábamos antes. Y no podían faltar los enunciados declarativos, en sí mismo no caracterizados formalmente para estas funciones, pero que se pueden emplear en contextos bien determinados.

En cambio, al descender al plano concreto del léxico, resulta más evidente la distinción de la modalidad deóntica respecto de las palabras especializadas en las otras modalidades. El lenguaje de la comedia antigua latina permite distinguir los usos pragmáticos en virtud de la caracterización de las unidades textuales cargadas de semántica, los personajes y las escenas. En el texto es posible determinar el rendimiento estilístico de las estructuras implicadas en la petición. Sin embargo, el autor no se detiene en esas realizaciones particulares porque prefiere destacar los rasgos definitorios de cada plano. Por tanto, en el léxico importa más describir la especialización de las distintas unidades en usos sintagmáticos concretos o en el enunciado de valor predominantemente peticionario. Con todo, a pesar de tal especialización de algunos de ellos, "todos los integrantes del campo léxico de la petición pueden funcionar en posición parentética para concretar la intencionalidad de un determinado mensaje" (p. 75). Se confirma así que la petición se combina con una gran variedad de mensajes al definir sobre todo relaciones muy generales entre emisor y receptores. El mensaje puede centrarse en estas exclusivamente o añadir informaciones detalladas a esa relación, en cuyo caso la petición parentética les propone un marco, y el interés se focaliza en el resto del enunciado.

Pero la interpretación de la petición desde la estructura interna del léxico implica detallar esta relación en un proceso en el que se encuentran otros campos semánticos. La recepción y la donación resultan entonces procesos ligados a la petición, así como la 
expresión alterna que frustra la recepción y la promesa preparatoria de las anteriores. Cuando se niega la petición se articulan otros procesos, e incluso se apela a uno de los conceptos que cohesionaban las relaciones comerciales y de convivencia en Roma: la fides, cuyo nombre participa de expresiones complejas con los verbos de petición.

Ahora bien, la estructura del léxico sirve a mismo tiempo a las funciones semánticas fundamentales a las que nos hemos referido, por lo que un aviso de ellas es muy pertinente cuando se trata de la configuración interna de este núcleo léxico (pp. 106-114). Esta justificación metodológica resulta muy oportuna porque los lexemas son abundantes, frecuentes en su uso pero sus rasgos aparecen dispersos en el desarrollo del campo al servir a relaciones tan abstractas. Tal dispersión se comprende además como una adaptación histórica a medida que la sociedad romana adquiría complejidad, por lo que se consigue con procedimientos de desarrollo léxico que progresan hasta la consolidación de la lengua literaria, como la modificación con proverbios y sufijos.

La estructura que definen las relaciones fundamentales del campo se articula según el grado de coactividad determinado fuera de la lengua, la eficacia rogativa y la intensidad de la petición que sí están discriminadas internamente. De ello se concluye que "lo pragmático, así, adopta materialización léxica en estos verbos y, a la inversa, el léxico recibe el influjo de lo pragmático" (p. 209).

Observemos las aplicaciones de lingüística general al conocimiento de las distintas lenguas indoeuropeas que sugiere este estudio, al tiempo que fundamenta un conocimiento cierto de las condiciones de uso del vocabulario latino. Precisamente a este grupo de interés puede satisfacer el repertorio final en el que se registra la lista de verbos, cada uno con unos rasgos esquemáticos acerca de su posición en el campo semántico, su uso y su representación en la lengua literaria, o en los registros especializados religioso o jurídico. A este respecto se observa la atención que a lo largo de las explicaciones se ha venido prestando a los usos técnicos del vocabulario. Su importancia se entiende en un plano de interpretación construido por la cultura romana con ayuda de la lengua. Emisor y receptores mantienen una comunicación definida por otras muchas reglas que no están en la estructura del latín. Pero esta estructura sugiere la elevación de ciertas unidades a ese plano de uso; por eso no es forzada ni totalmente convencional la especialización y tiene un sustento coherente con la lengua no especializada.

Los temas que se han ido suscitando al hilo que ha ido tendiendo el autor resultan muy sugestivos y seguro que muchos de ellos serán materia de discusión en adelante. Depende de la perspectiva desde la que construyamos nuestra descripción podemos profundizar más en algunos aspectos. Pero creo que el haber unido coherentemente tantas facetas pertinentes a la caracterización de los verbos latinos no desmerece la importancia de esos problemas y proporciona evidencias a un modelo teórico recurrente que es la lengua como sistema. Más aún cuando se describe una lengua antigua y conocida por una variedad limitada de textos. 



\section{Pascual Pérez y Rodríguez, La urna sangrienta o El panteón de Scianella, edición de Mi- riam López Santos, Madrid, Editorial Siruela, 2010, 300pp.}

Desde las oquedades de la literatura de principios del siglo XIX, como si de una aparición se tratara, dos siglos después ha visto su reedición la olvidada novela de Pascual Pérez y Rodríguez, escritor y fotógrafo valenciano, pero sobre todo pilar decisivo junto a Alberto Lista, Mariano de Cabrerizo y otros muchos que contribuyeron con sus aportaciones y habilidades artísticas a enaltecer el estado de las letras españolas.

Hubo de ser Miriam López Santos, la joven doctora que meses antes había defendido su tesis doctoral La novela gótica en España (1788-1833) y en la que dejaba patente la existencia de una novela gótica en España, heredera directa de la novela gótica clásica, cuyos máximos representantes los encontramos en M. G. Lewis y su obra maestra de El monje y por otro lado en Ann Radcliffe con Los misterios de Udolfo. Después de un largo peregrinaje por las bibliotecas de nuestro país, López Santos dio con uno de los ejemplares de aquella primera y única edición de La urna sangrienta en la Biblioteca de Cataluña que databa de 1834 y gracias a su fructuosa labor hoy podemos saborear las mieles de una novela gótica con firma española bajo su edición y prologada por Luis Alberto de Cuenca.

Pascual Pérez y Rodríguez (Valencia, 1804-1868), movido por una constante inquietud intelectual, ejerció como periodista, fotógrafo, profesor e incluso sacerdote escolapio, aunque esta última ocupación tuvo que abandonarla por incompatibilidad con su dedicación política y literaria. Fundó El diario mercantil y Psiquis, el primer periódico dirigido exclusivamente a mujeres. Además de ésta, publicó otras dos novelas góticas, La torre gótica o El espectro de Limberg y El hombre invisible o Las ruinas de Munsterhall.

En la urna sangrienta, Ambrosio, al igual que sucediera con el Montoni radcliffiano, es un ser malvado que representa el lado más oscuro de la naturaleza humana. Manifiesta estallidos de locura, incontrolables impulsos satánicos y una necesidad acuciante de derramar sangre. La trama se desarrolla en un entramado sublime, en el que gracias a la recreación detallada del narrador, acudiremos como lectores a un decorado propio de un escenario de terror. El punto neurálgico de la acción tiene lugar en el palacio de Scianella y sus inmediaciones, entre las que se encuentran, como ingrediente indispensable en toda novela gótica que se precie, las ruinas de un castillo con sus imponentes torreones a punto de derruirse, un conjunto de galerías, subterráneos y pasadizos que en ninguna ocasión servirán como refugio, sino que sus paredes serán testigo de la desazón que acompañará no sólo a sus personajes sino siempre en última instancia al propio lector, obteniéndose así ese efecto tan esperado que trata de aterrorizar, horrorizar, impresionar, asustar y emocionar al lector más allá de su memoria racional. 
Cada uno de los personajes cumple a rajatabla los preceptos góticos y la naturaleza emocional que los identifica con el género. En Mandina y Ambrosio se reencarna la polarización del bien y el mal. La doncella es un ser frágil, caracterizada por su castidad y pureza. Su integridad psicológica y física se ven amenazadas por el villano, ya que únicamente cuenta con su virtud para enfrentar al mal. Mientras que Ambrosio no deja de ser una criatura atroz que persigue sin piedad a la doncella mientras huye de sus propios impulsos oscuros, debatiéndose en su interior una lucha entre el bien intrínseco que poseía y el mal al que la sociedad y una educación desviada le han entregado.

A su vez aparecen los indispensables criados, en este caso Cenón como reconductor de la vida de Ambrosio y el contrapunto negativo: Coscia, quien fue el educador de Ambrosio en su juventud y el que se descubre como el artífice de su condena.

Pascual Pérez y Rodríguez transforma, en cierta medida, la novela gótica popular en un instrumento de protesta social, empleando los decorados y situaciones góticas para llamar la atención sobre horrores sociales o políticos tales como las leyes injustas o la lamentable situación de la mujer, y en el caso español de principios del siglo XIX no debemos olvidar la presencia de la Inquisición que hacía estragos en la sociedad con su censura, sus exigencias moralistas e intransigentes. Pero nuestro autor valenciano intentaba edificar, además de horrorizar a los lectores, combinando el terror gótico con una ideología radical para despertar la conciencia social y cambiar las opiniones de los lectores sobre ciertos asuntos. Sirve su novela de modelo como ejemplificación contra los vicios, y por eso al final de la obra acudimos a una justificación de todos los tópicos góticos utilizados para obtener una enseñanza moral.

Con la reedición de La urna sangrienta Miriam López Santos consigue que la literatura española vuelva la vista hacia su pasado, hacia los orígenes en definitiva de un género al que durante siglos se le negó su existencia en nuestras letras, pero que sin embargo no sólo gracias a la recuperación de esta novela que nos demuestra la calidad literaria del gótico de principios del XIX, sino también gracias al exhaustivo estudio que López Santos realiza en las primeras páginas junto al elegante prólogo con el que abre la lectura Luis Alberto de Cuenca, asistimos a un interesante descubrimiento del género gótico, tan denostado a los siglos, pero que se nos redescubre como un mundo que aporta luz más allá de tanta muerte y horror. Podemos considerarlo un flamante inicio para la recuperación de obras completamente desconocidas para la gran mayoría del público español, pero que con iniciativas y apuestas como la que han hecho tanto Miriam López Santos como la editorial Siruela podrían pasar a formar parte de nuestras bibliotecas y de nuestro imaginario en los próximos años, fomentando a su vez la reedición de otra serie de novelas que esperan su nueva oportunidad igualmente.

Siridia Fuertes Trigal 


\section{José Carlos González Boixo (ed.), Tendencias de la narrativa mexicana actual, ed. Ibero- americana-Vervuert-Bonilla Artigas, Madrid, 2009, 277 pp.}

Los estudios que se reúnen en este volumen han surgido en el marco de un Proyecto de Investigación patrocinado por el Ministerio de Educación y Ciencia de España. Lo conforman un total de nueve artículos que profundizan en las tendencias más representativas de la narrativa mexicana de los últimos años. El año 1968, se trata, tal y como advierte el editor, de una fecha que ha sido fijada por la crítica literaria con frecuencia como una fecha simbólica en el devenir de la literatura de este país, y particularmente en el género mencionado.

José Carlos González Boixo, como editor del libro, realiza la introducción y se detiene en la descripción de cuál ha sido la evolución de la narrativa mexicana entre 1968 y la generación de la década de los años setenta. Resume algunas tendencias significativas del período narrativo analizado y su contribución sirve de preámbulo al sumario de estudios contenidos en este libro. A continuación se reseñan las diversas aportaciones críticas.

Rosa María Díez Cobo, en su artículo "La reescritura de la historia en la narrativa mexicana contemporánea", afronta la temática histórica a finales de los años setenta en la narrativa mexicana. Desarrolla en una sección introductoria un sucinto pero exhaustivo repaso a los conceptos historiográficos que han tratado la reescritura de la historia, para posteriormente analizar someramente algunas de las características que singularizan y que permiten individualizar el fenómeno narrativo de la novela histórica contemporánea en el marco mexicano y, por extensión, latinoamericano. A continuación, y con la intención de esbozar los aspectos destacados en el marco de la novela histórica mexicana contemporánea, la autora selecciona tres relatos paradigmáticos por su integración crítica de historia y ficción y por su recurso a las diversas estrategias discursivas propias de la nueva novela histórica: Las obras son: $\mathrm{La}$ noche de Tlatelolco de Elena Poniatowska (1971), Terra Nostra de Carlos Fuentes (1975) y Cielos de la Tierra de Carmen Boullosa (1997).

Natalia Álvarez Méndez intenta demostrar en "La narrativa escrita por mujeres desde 1968 a la actualidad" que la teoría y crítica literarias feministas no han de asociarse a exclusiones o dogmatismos, pues la riqueza de los estudios de género radica en la revisión de anteriores cánones y en el reconocimiento de la pluralidad de voces y miradas femeninas que destacan en el ejercicio de la escritura. La autora sostiene que el discurso femenino no nace de un condicionamiento genético sino histórico y social, por lo cual no ha de atenderse a la idea de sexo aunque sí a la de género sumada a las circunstancias específicas vividas por las mujeres. De ahí que las autoras hispanoamericanas den lugar, con los personajes y las tramas que crean, a una ideología de género, muy contextualizada, que teje complejas redes de significaciones 
en las que el sexo, raza, posición social y situación política inciden en las nociones de individuo, sociedad y nación. Desde esta perspectiva se acerca a la narrativa femenina mexicana, relacionada en gran medida con el testimonio de marginación y con la reivindicación de libertad. Como colofón analiza la novela Como agua para chocolate de Laura Esquivel, en la que tras una serie de argumentos, Natalia Álvarez Méndez señala que hay un feminismo latente debajo de esa estructura superficial de folletín o novela rosa y de libro de recetas de cocina en el que se presenta la discriminación de la mujer en la sociedad.

Javier Ordiz Vázquez en “Incursiones en el reino de lo insólito. Lo fantástico, lo neofantástico y lo maravilloso en la narrativa contemporánea" lleva a cabo un sucinto repaso a las obras que en los últimos años se han escrito en las tendencias recogidas en el título, deteniéndose en una breve aclaración y demarcación de cada uno de los conceptos. Parte de los orígenes de lo fantástico en México, tomando como punto de partida el relato de Lanchitas de Jose María Roa Bárcena en 1878 hasta llegar a autores de la Generación de Medio Siglo como Juan José Arreola, Guadalupe Dueñas o Elena Garro. Dentro de las tendencias actuales de lo fantástico que se han cultivado en México en los últimos cuarenta años, el autor identifica tres manifestaciones de lo fantástico con sus respectivos autores:

. El fantástico «clásico»: Pacheco, Fuentes y Solares. El «relato de horror».

. Lo neofantástico: Tario y Aridjis. El realismo mágico.

- Alberto Chimal y otros narradores de lo maravilloso.

Tomás Regalado López, en su artículo “Del boom al crack: anotaciones críticas sobre la narrativa hispanoamericana del nuevo milenio", analiza el grupo del crack en el contexto de la narrativa hispanoamericana de principios del siglo XXI y para ello revisa la historia de dicho grupo desde sus inicios, con los encuentros de sus propios integrantes a finales de los ochenta, hasta la consideración del mismo dos décadas después, cuando ya se han afianzado con cierta proyección tanto dentro como fuera del mundo hispánico. El autor recoge una caracterización sobre el crack para poder entenderlo como grupo, generación o tendencia siempre en el marco de la tradición hispanoamericana en una asociación con la novela del boom y sobre todo respecto al cuestionamiento de las falsas continuaciones del realismo mágico que tan en boga se pusieron en los años setenta y ochenta. En último lugar Tomás Regalado López señala en su artículo los vínculos ente las novelas escritas por los integrantes del crack y los postulados teóricos que habían revelado tanto en el «Manifiesto Crack» de 1996 como en el libro posterior de Crack. Instrucciones de uso, del año 2004.

Francisca Noguerol Jiménez, con su artículo "Entre la sangre y el simulacro: últimas tendencias en la narrativa policial mexicana", incursiona en el relato de detectives, también denominado neopolicial y cultivado entre otros por Paco Ignacio Taibo II. De esta manera, la autora comienza su análisis tomando como punto de partida la narrativa policial mexicana anterior a 1968, lo que califica como el reinado del Whodunit. Posteriormente, en los años setenta tiene lugar la configuración de un nuevo canon, el llamado Hard Boiled, cuyo apogeo concluiría con la llegada del 
neopolicial, entre cuyos rasgos identificatorios propios Francisca Noguerol destaca la relegación del enigma a un segundo plano, la presencia de la ley y la sociedad como responsables de los crímenes, la primacía de los otros en la trama, así como las huellas del periodismo y la impronta de la realidad. La autora incide asimismo en la aparición de otra serie de características propias del género como son la descentralización de los escenarios, el hecho de que las tramas no se desarrollen únicamente en D.F. sino también en provincias y en la frontera, la huella de medios masivos de comunicación como pueden ser la música, el cine, la televisión o el cómic y la hibridación con otros formatos narrativos.

Nina Pluta en "El género seudocriminal. Inspiraciones policíacas en las novelas mexicanas del cambio de siglo" demuestra cómo la novela mexicana en este cambio de siglo continúa recibiendo la influencia del género criminal, tal y como podemos observar en numerosos relatos que se ven impregnados por esta tendencia a pesar de no pertenecer al género propiamente dicho. Son las novelas denominadas seudopoliciales y en las que Nina Pluta incluye como cultivadores a Sergio Pitol, Juan Villoro, Jorge Volpi, Ignacio Padilla y Guillermo Fadanelli. Son textos en los que encontramos diversas extensiones metafóricas del crimen, que acaba convirtiéndose en muchas ocasiones en destino, voluntad de un supremo hacedor, en un crimen fundacional histórico o en el acto transgresivo de la razón humana. En definitiva, el mal está presente en una gran parte de las novelas mexicanas y el esquema tradicional del género se muestra ineficaz para recoger nuevas inquietudes y necesidades de los tiempos actuales.

Imelda Martín Junquera, en su artículo “Ecocrítica, racismo medioambiental y renacimiento chicano", centra su atención en la literatura chicana que escriben los mexicanos del sudoeste de los Estados Unidos. Una literatura de denuncia en la que se manifiestan no sólo las costumbres, las tradiciones y los ecosistemas del otro lado de la frontera mexicana, sino, y sobre todo las condiciones de racismo medioambiental en las que viven y trabajan estos mexicano-americanos. En este contexto surgen conceptos como barrio frente a valle, lo que delimita las diferencias entre las poblaciones rurales o urbanas.

En último lugar, Kristine Vanden Berghe, con su artículo "Desde las montañas del sureste", completa un recorrido por las diversas tendencias de la narrativa mexicana al incluir un interesante análisis de la trascendencia y el valor literario de los textos del Subcomandante Marcos, cuya prosa ha sido muy apreciada por diferentes críticos y escritores mexicanos. Así, Kristine Vanden Berghe profundizará en aspectos significativos de los relatos de ficción partiendo del análisis de los protagonistas de los mismos: El Viejo Antonio, Don Durito de la Lacandona, Elías y otros muchos personajes que en opinión de Vanden Berghe son trasuntos del autor. Son relatos que, como podemos concluir, ocultan un discurso tan ideológico como cualquier discurso político, pero a pesar de ello es patente que, con el paso de los años y la evolución de sus textos, el autor se ha esforzado por evitar que se lean de esa manera.

Como conclusión, podemos decir que nos encontramos ante un volumen caracterizado por su pluralidad temática en la narrativa mexicana actual, que 
proporciona la posibilidad de una consulta independiente de los artículos, según la conveniencia y el interés de cada lector. Sea ésta o no la intención del editor, no cabe duda de que el hecho de contar con tantos puntos de vista distintos nos da una idea de la enorme riqueza que encierra la temática propuesta y constituye, al mismo tiempo, uno de los mayores atractivos de la obra. La mencionada variedad se complementa con una lectura rápida y amena, por lo que la persona que se acerque a sus páginas recibirá una panorámica general del tema diversa y enriquecedora.

Siridia Fuertes Trigal 
Miriam López Santos, La novela gótica en España (1788-1833), Vigo, Editorial Academia del Hispanismo, 2010, 310 pp.

Una literatura que dependa del presente, del ahora, del aquí, es efímera y perece rápidamente, tal y como afirmara Mario Vargas Llosa, de ahí la importancia que cobran estudios tan reveladores como el de la profesora Miriam López Santos, que con esta valiosa aportación a la historia de la literatura realiza una de las principales labores del teórico: la recuperación de la propia literatura. Especialistas como Luis Alberto de Cuenca, David Roas, Guillermo Carnero o $\mathrm{M}^{\mathrm{a}}$ José Alonso Seoane en sus estudios sobre diversos aspectos del panorama de la teoría literaria española trazaron breves pinceladas sobre la literatura gótica española, pero no ha sido hasta la llegada del presente libro, La novela gótica en España (1788-1833) de Miriam López Santos, el momento en el que abiertamente podremos hablar de novela gótica con firma española, en el que ya no intuiremos esporádicos brochazos sino que, como lectores, estudiosos o simples curiosos podremos pasearnos por una galería repleta de explicaciones con base sociológica, histórica y literaria acerca de la existencia de dicho género dentro de nuestras fronteras. Marcará este libro un antes y un después dentro de la teoría sobre la novela gótica española y de seguro se convertirá con el paso del tiempo en un referente ineludible para todo estudioso que se aproxime al mundo gótico.

López Santos desarrolla en este estudio teórico literario las circunstancias y motivos históricos, sociológicos, así como los literarios y estéticos que favorecieron la implantación y el éxito de la novela gótica como género de masas en España. Tras su nacimiento y auge en la Inglaterra del siglo de las luces, se importó en España pero fue adquiriendo características propias, adaptándose de esta manera a los preceptos culturales y sociales que caracterizaban a la España de la Ilustración y del siglo XVIII en general, lo que en definitiva le permite a la autora hablar de la particularidad hispánica, frente a su forma original. El peso de la moral, la exaltación de la religión, pero también la búsqueda incesante de la verosimilitud literaria y de un notorio realismo, así como la presencia constante del elemento macabro se habrían de configurar como nuevas características o elementos estructurales exigidos por la renovada fórmula de la novela gótica.

La novela gótica en España (1788-1833) ahonda en estas especiales circunstancias puesto que son las que permiten establecer un corpus de novelas, ya que condicionaron de manera decisiva la adaptación de la ficción gótica en nuestro país y por eso la autora dedica un apartado del libro a la transferencia genérica concretándolo en la novela gótica española. Para ello describe minuciosamente la evolución de la novela gótica española desde sus primeras manifestaciones hasta la explosión de la novela gótica en España teniendo siempre en cuenta sus particularidades desde el punto de vista de los propios traductores y autores, tal y como manifiestan en los prólogos de dichas obras. 
Como colofón a este apartado encontramos el análisis de la Galería fúnebre de Agustín Pérez Zaragoza, ejemplo de un caso concreto de adaptación.

En la fase de consolidación y ocaso del género, dentro de las novelas góticas españolas distingue López Santos entre la novela gótica española de impulso racional y la que se relaciona con "lo irracional". Afirma la autora que constituyen dos impulsos que escindieron el género en dos vertientes opuestas pero complementarias en su origen: la racional terrorífica que busca el miedo, escondido tras el velo de la veracidad histórica, y la irracionalista que abandona el componente sobrenatural, que se recrea en el placer del horror, que da rienda suelta a la monstruosidad y que juega con la angustia y el sufrimiento a través de una lección moral bastante debilitada.

El resultado del exhaustivo estudio que López Santos efectúa en los apartados concernientes a las circunstancias y motivos, por un lado, y a la transferencia genérica, por otro, es una catalogación de las novelas góticas españolas, y ahí encontraremos una serie de novelas que se suceden a lo largo de tres momentos o etapas: unas novelas con motivos góticos que abarca desde los primeros ecos, en las dos últimas décadas del siglo XVIII, hasta su desarrollo pleno en los años finales del régimen absolutista de Fernando VII en las que nos hallaríamos ante las novelas góticas españolas propiamente dichas, pasando por el asentamiento del género a través de los textos importados en lo que denomina la autora "novelas adaptadas".

Esta, en suma, es una excelente aproximación tanto para expertos en la materia como para futuros investigadores que consigue no sólo profundizar en un género relativamente desconocido como ha sido hasta el momento la novela gótica, sino que al mismo tiempo consigue dar la vuelta a través de interesantes estudios a las conexiones, ya lugares comunes, entre sociedad, historia y literatura.

Siridia Fuertes Trigal 